\title{
Effective Sol-Gel Nanocoatings on ZnO Electrodes for Suppressing Recombination in Dye-Sensitized Solar Cells
}

\author{
Shintaro Ueno and Shinobu Fujihara \\ Department of Applied Chemistry, Faculty of Science and Technology, Keio University, 3-14-1 Hiyoshi, Kohoku-ku, \\ Yokohama 223-8522, Japan \\ Correspondence should be addressed to Shinobu Fujihara, shinobu@applc.keio.ac.jp
}

Received 3 February 2012; Accepted 16 April 2012

Academic Editor: David Worrall

Copyright $\odot 2012$ S. Ueno and S. Fujihara. This is an open access article distributed under the Creative Commons Attribution License, which permits unrestricted use, distribution, and reproduction in any medium, provided the original work is properly cited.

\begin{abstract}
Attempts have been made to improve the performance of dye-sensitized solar cells by forming metal-oxide nanocoating layers on $\mathrm{ZnO}$ electrodes by a sol-gel transformation. $\mathrm{SiO}_{2}, \mathrm{Nb}_{2} \mathrm{O}_{5}, \mathrm{TiO}_{2}$, or $\mathrm{ZrO}_{2}$ nanocoating layers could be formed by dipping $\mathrm{ZnO}$ films into metal alkoxide solutions of low concentrations and subsequent heat treatments. The performance of DSSCs using the coated $\mathrm{ZnO}$ electrodes depends strongly on the structure of coating layers such as the thickness and the surface coverage, which are significantly influenced by the coating conditions. In particular, $\mathrm{SiO}_{2}$ and $\mathrm{Nb}_{2} \mathrm{O}_{5}$ coating layers are effective to suppress the recombination by constructing the energy barrier at the $\mathrm{ZnO} /$ electrolyte interface and enhance energy conversion efficiency. It is found that the coating layers also hinder the grain growth of $\mathrm{ZnO}$, contributing to the enhanced cell performance as well.
\end{abstract}

\section{Introduction}

Conventional photovoltaic devices are based on light harvesting and charge separation at semiconductor $\mathrm{p}$-n junctions. In contrast, dye-sensitized solar cells (DSSCs) utilize a combination of wide-gap semiconductors and organic or metal-organic complex dyes which play a fundamental role in light harvesting. DSSCs are expected as one of the promising candidates to partially replace conventional silicon-based solar cells because of their low manufacturing cost and higher conversion efficiency over 10\% [1]. Furthermore, since DSSCs are also applicable to colorful, lightweight, and flexible devices, they can be installed in many kinds of places. Common DSSCs are composed of a conductive transparent glass substrate, a metal oxide layer, dye-sensitizers chemically bonded to metal oxides, a liquid electrolyte, and a counter electrode. In particular, an assembly of the conductive transparent glass substrate and the dye-sensitized n-type metal oxide semiconductor layer is called a photoanode, which is an essential part of DSSCs.

$\mathrm{TiO}_{2}$ is recognized as the most common electrode material for DSSCs because the $\mathrm{TiO}_{2}$-based cells generally have higher-energy conversion efficiencies. Many kinds of metal oxide semiconductors other than $\mathrm{TiO}_{2}$ have also been applied to electrodes of DSSCs [5]. Among them, $\mathrm{ZnO}$ is the most promising alternative to $\mathrm{TiO}_{2}$. Many researchers have tried to enhance the performance of $\mathrm{ZnO}$-based DSSCs by modifying nanostructures of electrodes. For example, Law et al. reported the energy conversion efficiency $(\eta)$ of $1.5 \%$ for a $\mathrm{ZnO}$ nanowire electrode [6]. Keis et al. reported porous $\mathrm{ZnO}$ electrodes fabricated by a doctor blading method showing $\eta=5 \%$ under lower irradiance at 0.1 sun [7]. Other structures have been reported later such as $\mathrm{ZnO}$ aggregate films comprising of closely packed nanocrystallites $(\eta=5.4 \%$, 1 sun), densely packed nanosheet $\mathrm{ZnO}$ films $(\eta=5.41 \%$, 1 sun), and $\mathrm{ZnO}$ nanoparticles-nanowire hybrid arrays $(\eta=$ $4.24 \%, 1$ sun) [8-10]. A more complicated structure of hierarchical $\mathrm{ZnO}$ nanowire electrodes showed the $\eta$ of $2.63 \%$ [11]. We have also focused on $\mathrm{ZnO}$ as an electrode material in our series of studies on DSSCs [12-18]. Wurtzite-type $\mathrm{ZnO}$ is an $n$-type semiconductor with a wide band gap of $3.37 \mathrm{eV}$ [19], which is similar to that of $\mathrm{TiO}_{2}(3.2-$ $3.3 \mathrm{eV})[20]$. A conduction band edge energy $\left(E_{\mathrm{CB}}\right)$ of $\mathrm{ZnO}$ is located just above an $E_{\mathrm{CB}}$ of $\mathrm{TiO}_{2}$, and a difference in 
$E_{\mathrm{CB}}$ is within $200 \mathrm{meV}$ between $\mathrm{ZnO}$ and $\mathrm{TiO}_{2}$ [21-23]. In addition, $\mathrm{ZnO}$ has a high electron mobility by $10^{7}$ times larger than that of $\mathrm{TiO}_{2}$ when measured in bulk crystals [24]. Thus, a similar electron injection behavior can be expected for both materials, and $\mathrm{ZnO}$ is assumed to be more advantageous in terms of transport of the injected electrons. In spite of these excellent properties of $\mathrm{ZnO}$, energy conversion efficiencies of $\mathrm{ZnO}$-based DSSCs are still lower than those of $\mathrm{TiO}_{2}$-based DSSCs. One of the reasons is lower open-circuit voltage $\left(V_{\mathrm{OC}}\right)$ of $\mathrm{ZnO}$-based cells (typically $0.55-0.65 \mathrm{~V})$ compared to that of $\mathrm{TiO}_{2}$-based cells $(0.75-$ $0.85 \mathrm{~V}$ ) when using $\mathrm{Ru}(\mathrm{II})$ complex sensitizers $[1,8,16]$. It is reported that a maximal $V_{\mathrm{OC}}$ is determined by an energy difference between $E_{\mathrm{CB}}$ of a semiconductor layer and the Nernst potential of an electrolyte $[1,5]$. Therefore, $\mathrm{ZnO}-$ based DSSCs are potentially comparable to $\mathrm{TiO}_{2}$-based cells in $V_{\mathrm{OC}}$ taking account of the large similarity in the band structure.

The difference in $V_{\mathrm{OC}}$ is due possibly to a recombination, namely, capturing photogenerated electrons in the conduction band of metal oxide semiconductor layers by oxidized species in an electrolyte. In an $\mathrm{I}^{-} / \mathrm{I}_{3}{ }^{-}$redox system, tri-iodide ions $\left(\mathrm{I}_{3}{ }^{-}\right)$can be related to the recombination. The relationship between $V_{\mathrm{OC}}$ and a recombination kinetic constant $\left(k_{b}\right)$ is represented by the following equation [25]:

$$
V_{\mathrm{OC}}=\left(\frac{k T}{e}\right) \ln \left(\frac{I_{\mathrm{inj}}}{n_{\mathrm{cb}} k_{b}\left[\mathrm{I}_{3}^{-}\right]}\right),
$$

where $k$ is the Boltzmann constant, $T$ is temperature, $e$ is the electron charge, $I_{\text {inj }}$ is the flux of injections, $n_{\mathrm{cb}}$ is the number of electrons in a conduction band, and $\left[\mathrm{I}_{3}{ }^{-}\right]$is a concentration of tri-iodide ions in an electrolyte. Equation (1) implies that the larger recombination rate constant leads to the lower $V_{\mathrm{OC}}$ values. Therefore, the recombination should be suppressed to improve the $V_{\text {OC }}$ values.

Some strategies have been conceived to suppress the recombination: (i) reducing the number of recombination sites, (ii) enhancing the electron transport inside electrodes, and (iii) constructing an energy barrier at an electrode/electrolyte interface. In $\mathrm{ZnO}$ electrodes, since the recombination sites correspond mainly to surface defects of $\mathrm{ZnO}$ particles, $V_{\mathrm{OC}}$ is supposed to be improved by decreasing surface areas of $\mathrm{ZnO}$ electrodes. A better electron transport is expected for the structure free from grain boundaries such as nanorods, nanowires, and nanorod/nanoparticle composite, which are also effective for enhancing $V_{\mathrm{OC}}[6,26]$. However, these ways (i) and (ii) are accompanied with a remarkable decrease in surface areas of electrodes, thereby resulting in a poor dye adsorption ability.

In the third way (iii), a formation of core-shell-type nanocoating layers, which act as an energy barrier for the recombination, on $\mathrm{ZnO}$ particles can reduce effectively the recombination kinetics constant $k_{b}$ [27]. A schematic energy diagram for the DSSC using an insulator-coated $\mathrm{ZnO}$ electrode is shown in Figure 1 with an illustration of an ideal coating layer structure. The difference in $E_{\mathrm{CB}}$ between $\mathrm{ZnO}$ and proper coating materials can work as an energy barrier for the recombination at the $\mathrm{ZnO} /$ electrolyte interface.
However, when $E_{\mathrm{CB}}$ of the coating material lies above the excited state of dye $\left(S^{*}\right)$, the coating layer also disturbs the electron injection from adsorbed dyes into the $\mathrm{ZnO}$ layer. Nonetheless, many works are found in the literature reporting that insulator-coated electrodes are utilized to enhance the cell performance by the suppression of the recombination $[28,29]$. Some researchers explain that the electron injection through ultrathin coatings of insulator electrodes is achieved by a tunneling effect $[29,30]$. In fact, the performance comparable to the $\mathrm{TiO}_{2}$ electrodes was reported for $\mathrm{SnO}_{2} / \mathrm{ZnO}$ electrodes [31].

In addition to the suppression of the recombination, metal-oxide coatings may be suitable for inhibiting aggregation of $\mathrm{Zn}^{2+} / \mathrm{Ru}$ (II) dye complexes or improving a long-term durability. For metal oxide nanocoatings on porous $\mathrm{ZnO}$ electrodes, we employed a dip-coating method using various kinds of metal alkoxide solutions. The coating solutions penetrate inside porous, thick $\mathrm{ZnO}$ films as electrodes. Then thin metal-oxide coatings are formed on the surface of $\mathrm{ZnO}$ particles by a sol-gel transformation including hydrolysis and condensation of the metal alkoxides as follows [32]:

$$
\begin{gathered}
\mathrm{M}(\mathrm{OR})_{m}+n \mathrm{H}_{2} \mathrm{O} \longrightarrow \mathrm{M}(\mathrm{OR})_{m-n}(\mathrm{OH})_{n}+n \mathrm{ROH} \\
\mathrm{M}-\mathrm{OH}+\mathrm{HO}-\mathrm{M} \longrightarrow \mathrm{M}-\mathrm{O}-\mathrm{M}+\mathrm{H}_{2} \mathrm{O}
\end{gathered}
$$

In this paper, we review our works for enhancing the performance of DSSCs by the formation of $\mathrm{SiO}_{2}$ and $\mathrm{Nb}_{2} \mathrm{O}_{5}$ nanocoating layers on $\mathrm{ZnO}$ electrodes $[2,3]$. Additionally, we also report our recent works for the application of $\mathrm{TiO}_{2}$ and $\mathrm{ZrO}_{2}$ nanocoatings to the $\mathrm{ZnO}$-based DSSCs.

\section{Experimental}

2.1. Fabrication of Porous $\mathrm{ZnO}$ Films. Porous, thick $\mathrm{ZnO}$ films used as a coating target were fabricated by a chemical bath deposition (CBD) method and subsequent pyrolytic transformation. Details of the fabrication process were reported previously [14]. Zinc acetate dihydrate $\left(\left(\mathrm{CH}_{3} \mathrm{COO}\right)_{2} \mathrm{Zn} \cdot 2 \mathrm{H}_{2} \mathrm{O} ; 99.0 \%\right.$ purity, Wako Pure Chemical Industries Co., Ltd., Japan) was dissolved in dehydrated methanol at a concentration of $0.15 \mathrm{M}$. Fluorine-doped tinoxide-coated glass substrates (FTO substrates; Nippon Sheet Glass Co., Ltd., Japan; sheet resistance of $10 \mathrm{ohm} \mathrm{sq}^{-1}$ ) were immersed in the resultant solution, which was kept at $60^{\circ} \mathrm{C}$ for $30 \mathrm{~h}$. Layered hydroxide zinc acetate (LHZA) films were formed on both sides of the FTO substrates. The unnecessary film on the bare glass side was completely removed by scratching. The film on the FTO substrate was heated at $450^{\circ} \mathrm{C}$ for $10 \mathrm{~min}$ in air to be converted to the porous, thick $\mathrm{ZnO}$ film (designated as the "uncoated" film).

2.2. Metal-Oxide Coating Method. Nanocoating layers were formed on the porous $\mathrm{ZnO}$ films through a dip-coating procedure. Four kinds of metal oxides were chosen as coating materials: $\mathrm{SiO}_{2}, \mathrm{Nb}_{2} \mathrm{O}_{5}, \mathrm{TiO}_{2}$, and $\mathrm{ZrO}_{2}$. Metal alkoxide solutions were used for precursors. For the $\mathrm{SiO}_{2}$ coating, a coating solution was prepared from $40 \mu \mathrm{L}$ of tetraethylorthosilicate (TEOS; $\left(\mathrm{C}_{2} \mathrm{H}_{5} \mathrm{O}\right)_{4} \mathrm{Si} ; 95.0 \%$ purity, Wako), $500 \mu \mathrm{L}$ of aqueous ammonia (28\% mass/mass; Wako), and $20 \mathrm{~mL}$ 


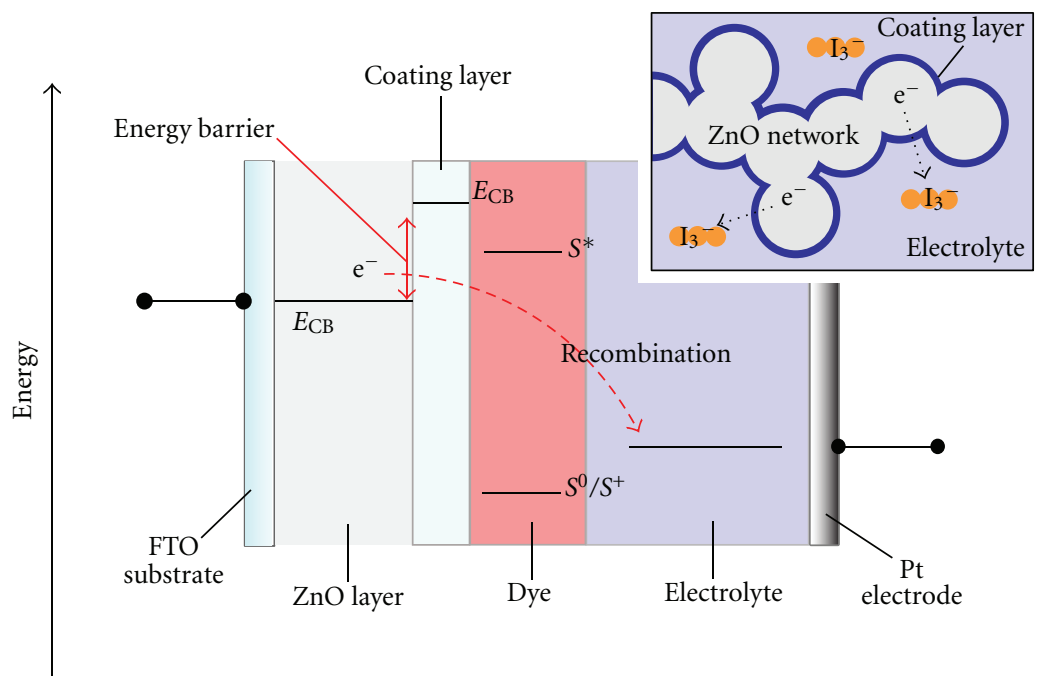

FIGURE 1: A schematic illustration of the suppression of the recombination by constructing an energy barrier at the $\mathrm{ZnO} / \mathrm{electrolyte}$ interface. An inset indicates the core-shell-type coating layer on the $\mathrm{ZnO}$ electrode.

of water [33]. For the $\mathrm{Nb}_{2} \mathrm{O}_{5}$ coating, $10-30 \mathrm{mM}$ ethanolic solutions of niobium pentaethoxide $\left(\left(\mathrm{C}_{2} \mathrm{H}_{5} \mathrm{O}\right)_{5} \mathrm{Nb} ; 99.9 \%\right.$ purity, Soekawa Chemicals Co., Ltd., Japan) were prepared as coating solutions. For the $\mathrm{TiO}_{2}$ and the $\mathrm{ZrO}_{2}$ coating, 10-30 mM ethanolic solutions of titanium tetraisopropoxide $\left(\left[\left(\mathrm{CH}_{3}\right)_{2} \mathrm{CHO}\right]_{4} \mathrm{Ti} ; 95.0 \%\right.$ purity, Wako) and $10-50 \mathrm{mM}$ 1-propanolic solutions of zirconium tetra- $n$-propoxide $\left(\left(\mathrm{C}_{3} \mathrm{H}_{7} \mathrm{O}\right)_{4} \mathrm{Zr} ; 23-28 \%\right.$ free alcohol, Strem Chemicals, Inc., USA) were prepared as coating solutions, respectively. The $\mathrm{ZnO}$ films were immersed in the respective coating solutions and withdrawn at a speed of $0.1 \mathrm{~mm} / \mathrm{sec}$ by using a Micro Speed Dip Coater (MS215, Asumi Giken Ltd., Japan). Then, the coated $\mathrm{ZnO}$ films were heated at $600^{\circ} \mathrm{C}$ for $10 \mathrm{~min}$ in air. We also prepared a reference sample by heating the uncoated $\mathrm{ZnO}$ film at $600^{\circ} \mathrm{C}$ for $10 \mathrm{~min}$ (the "uncoated/heated" film).

2.3. Characterization. The crystal structure was identified by X-ray diffraction (XRD) analysis (Bruker, AXS D8-02) using $\mathrm{CuK} \alpha$ radiation. The Scherrer diameter of particles constituting the sample films was calculated with the Scherrer equation from the recorded XRD data. The morphology of the sample films was observed by field-emission scanning electron microscopy (FESEM; Hitachi, S-4700). The structure of the metal-oxide coating layers was examined by field-emission transmission electron microscopy (FETEM; FEI, Sirion or Tecnai Spirit) and X-ray photoelectron spectroscopy (XPS; JEOL, JPS 9000 MX).

2.4. Evaluation of Cell Performance. The uncoated and the coated $\mathrm{ZnO}$ films were dyed by immersion in a $0.3 \mathrm{mM}$ ethanolic solution of $\mathrm{RuL}_{2}(\mathrm{NCS})_{2}: 2 \mathrm{TBA}\left(\mathrm{L}=2,2^{\prime}-\right.$ bipyridyl-4,4' -dicarboxylic acid and TBA = tetrabutylammonium; N719, Solaronix SA, Switzerland) at $60^{\circ} \mathrm{C}$ for $30 \mathrm{~min}$. For $J-V$ measurements, sandwich-type open cells were constructed with the $\mathrm{ZnO} / \mathrm{N} 719$ photoanode, a $50 \mu \mathrm{m}$-thick spacer film, and a counter platinum electrode. The $\mathrm{I}^{-} / \mathrm{I}_{3}{ }^{-}$ redox couple electrolyte, which was composed of $0.1 \mathrm{M} \mathrm{LiI,}$ 50 mM I2, 0.6 M 1,2-dimethyl-3-propylimidazolium iodide, $1 \mathrm{M}$ 4-tert-butylpyridine, and 3-methoxypropionitrile, was introduced between the electrodes. The characteristic values, $V_{\mathrm{OC}}$, short-circuit photocurrent density $\left(J_{\mathrm{SC}}\right)$, fill factor (ff), and $\eta$, were determined from the $J-V$ measurements. The active cell area was fixed at $25 \mathrm{~mm}^{2}$ by a mask. A $500 \mathrm{~W}$ Xe lamp (Ushio, UXL-500SX) was used as the light source to produce the simulated AM 1.5 illumination at $100 \mathrm{~mW} / \mathrm{cm}^{2}$. An AM 1.5 filter, a water filter, and an infrared cut filter (Hoya, S76-HA50) were placed in the light path to regulate light in the wavelength range of $300-800 \mathrm{~nm}$, reducing the mismatch of the simulated sunlight. $J-V$ curves were measured under the simulated sunlight with a potentiostat (Hokuto Denko, HSV-100).

The amount of dyes adsorbed on the electrodes was estimated by removing them in a $0.5 \mathrm{M} \mathrm{NaOH}$ ethanol/water $(v / v=1)$ solution. The absorbance of the resultant dye solutions was measured by a spectrophotometer (Hitachi, U3300 or Jasco, V-670) and calibrated with a standard solution of N719.

\section{Results and Discussion}

3.1. Structure of $\mathrm{SiO}_{2}$ - and $\mathrm{Nb}_{2} \mathrm{O}_{5}$-Coated $\mathrm{ZnO}$ Films. The film obtained by the CBD method was identified as LHZA with the chemical formula of $\mathrm{Zn}_{5}(\mathrm{OH})_{8}\left(\mathrm{CH}_{3} \mathrm{COO}\right)_{2} \cdot 2 \mathrm{H}_{2} \mathrm{O}$. They had a unique flower-like morphology. The LHZA film could be converted into $\mathrm{ZnO}$ completely by pyrolysis at $450^{\circ} \mathrm{C}$ for $10 \mathrm{~min}$. An FESEM image of the resultant $\mathrm{ZnO}$ film is shown in Figure 2(a), where the flower-like morphology originated from the LHZA film is maintained well. There exist micrometer-sized spaces inside as well as between the flower-like $\mathrm{ZnO}$ units, which can facilitate the penetration of the coating solutions in the coating process, the dye loading during the immersion in the dye solution, and the diffusion of the electrolyte in the solar-cell operation. 


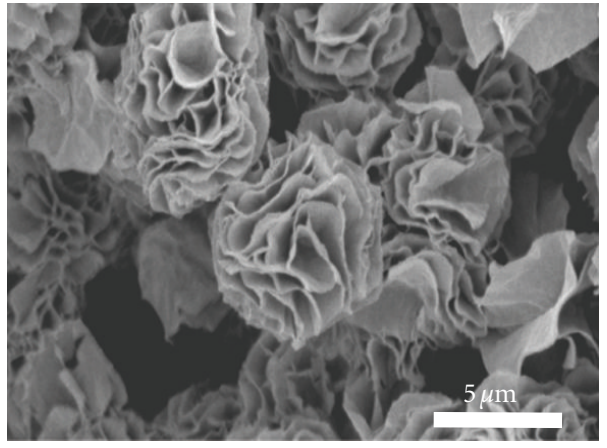

(a)

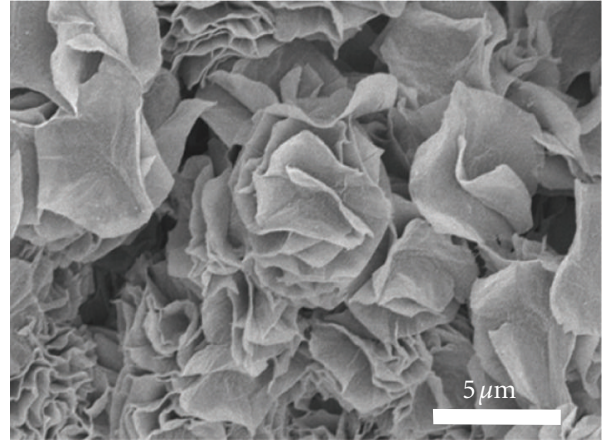

(b)

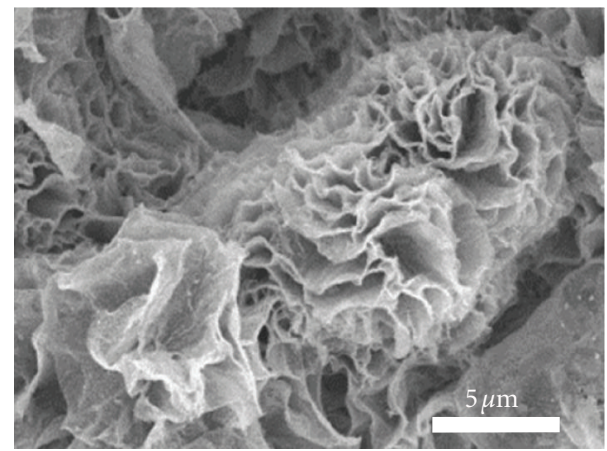

(c)

Figure 2: FESEM images of (a) the uncoated $\mathrm{ZnO}$, (b) the $\mathrm{SiO}_{2}$-coated $\mathrm{ZnO}$, and (c) the $\mathrm{Nb}_{2} \mathrm{O}_{5}(10 \mathrm{mM})$-coated $\mathrm{ZnO}$ film [2-4].

Figures 2(b) and 2(c) show FESEM images of the films that were coated with the TEOS solution and the $10 \mathrm{mM}$ $\left(\mathrm{C}_{2} \mathrm{H}_{5} \mathrm{O}\right)_{5} \mathrm{Nb}$ solution, respectively, and subsequently heated at $600^{\circ} \mathrm{C}$ for $10 \mathrm{~min}$ (denoted as the " $\mathrm{SiO}_{2}$-coated" and the " $\mathrm{Nb}_{2} \mathrm{O}_{5}(10 \mathrm{mM})$-coated" film, resp.). The flower-like morphology of the $\mathrm{ZnO}$ film does not change after the $\mathrm{SiO}_{2}$ and the $\mathrm{Nb}_{2} \mathrm{O}_{5}$ coating. The thickness of the coated films (approximately $30 \mu \mathrm{m}$ ) was also the same as that of the $\mathrm{ZnO}$ film. Therefore, it is not necessary to consider influences of dissolution or morphological change in discussing the structure and properties of the coated $\mathrm{ZnO}$ films.

The presence of the coating materials was confirmed by XPS. Figure 3(a) compares XPS spectra in the Si $2 p$ region for the uncoated and the $\mathrm{SiO}_{2}$-coated $\mathrm{ZnO}$ film. While no peak is detected for the uncoated $\mathrm{ZnO}$ film in this region, a peak due to the Si 2p electrons is clearly observed at $102.0 \mathrm{eV}$ for the $\mathrm{SiO}_{2}$-coated $\mathrm{ZnO}$ film, supporting the presence of $\mathrm{SiO}_{2}$ in the coated film. We also tried to observe directly the $\mathrm{SiO}_{2}$ coating layers by FETEM. Figure 4 shows an FETEM image of the $\mathrm{SiO}_{2}$-coated $\mathrm{ZnO}$ particles found in the film. The coreshell-type $\mathrm{SiO}_{2}$ coating layers with a thickness of $1-3 \mathrm{~nm}$ are formed on the surface of the $\mathrm{ZnO}$ particles. We have reported previously that the structure of the silica layers, such as the thickness and the surface coverage, depends on the TEOS concentration and the coating time [4]. Basically, in the presence of the diluted ammonia catalyst, the formation of an amorphous $\mathrm{SiO}_{2}$ layer proceeds as the following hydrolysis and condensation reactions [32]:

$$
\begin{gathered}
\mathrm{Si}\left(\mathrm{OC}_{2} \mathrm{H}_{5}\right)_{4}+n \mathrm{OH}^{-} \longrightarrow \mathrm{Si}\left(\mathrm{OC}_{2} \mathrm{H}_{5}\right)_{4-n}\left(\mathrm{O}^{-}\right)_{n}+n \mathrm{C}_{2} \mathrm{H}_{5} \mathrm{OH} \\
\equiv \mathrm{Si}-\mathrm{OH}+\mathrm{O}^{-}-\mathrm{Si} \equiv \longrightarrow \equiv \mathrm{Si}-\mathrm{O}-\mathrm{Si} \equiv+\mathrm{OH}^{-}
\end{gathered}
$$

Because of the lower stability of TEOS in the aqueous system, the reactions might proceed rapidly. Then the core-shell structure is formed by the reaction between the surface $\mathrm{OH}$ groups of the $\mathrm{ZnO}$ particles and the hydrolyzed TEOS. Actually, the thin $\mathrm{SiO}_{2}$ nanocoating layers were successfully formed by using the low TEOS concentration of approximately $9 \mathrm{mM}$ and the relatively short coating time (the $\mathrm{ZnO}$ film was immersed in the coating solution only for a few minutes). It should be noted that the thin shell layers could cover partially the surface of the $\mathrm{ZnO}$ particles in such the condition.

The $\mathrm{SiO}_{2}$ coating layers were in the amorphous state regardless of the subsequent heat treatments. In contrast, for the crystalline metal oxide coatings, it is important to know crystalline phases formed in the sol-gel transformation under the given experimental conditions. Since niobium is a multivalent metal element, there are various stoichiometries found in niobium oxides, $\mathrm{Nb}_{x} \mathrm{O}_{y}$. Moreover, as far as $\mathrm{Nb}_{2} \mathrm{O}_{5}$ 


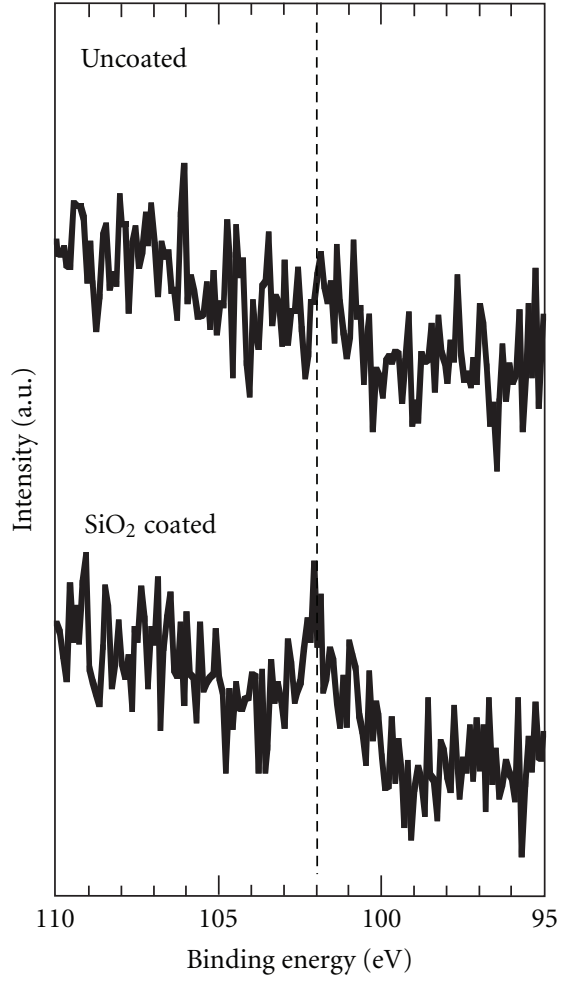

(a)

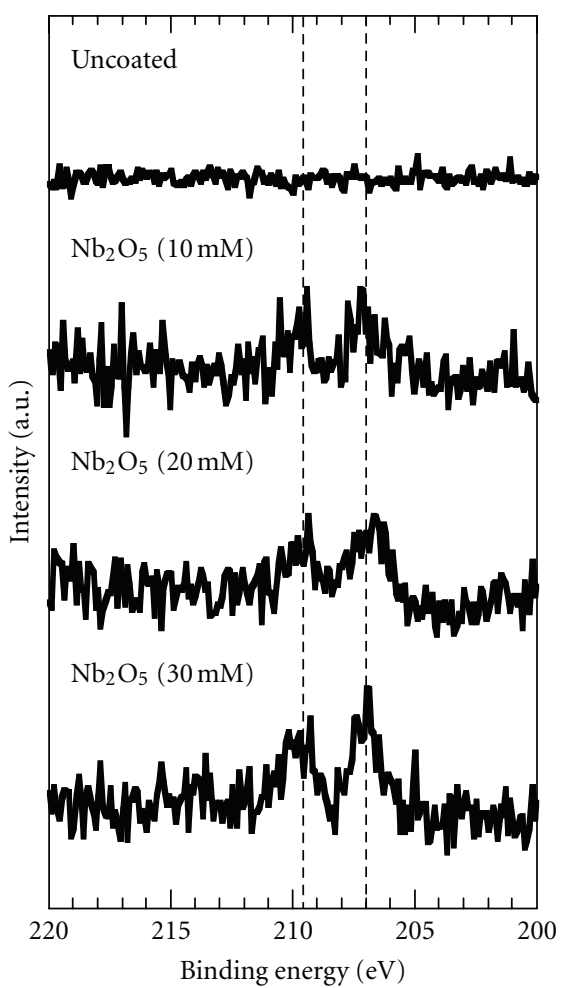

(b)

FIGURE 3: XPS spectra (a) in the $\mathrm{Si} 2 \mathrm{p}$ region for the uncoated and the $\mathrm{SiO}_{2}$-coated electrodes and (b) in the Nb $3 \mathrm{~d}$ region for the uncoated and the $\mathrm{Nb}_{2} \mathrm{O}_{5}$-coated electrodes $[2,3]$.

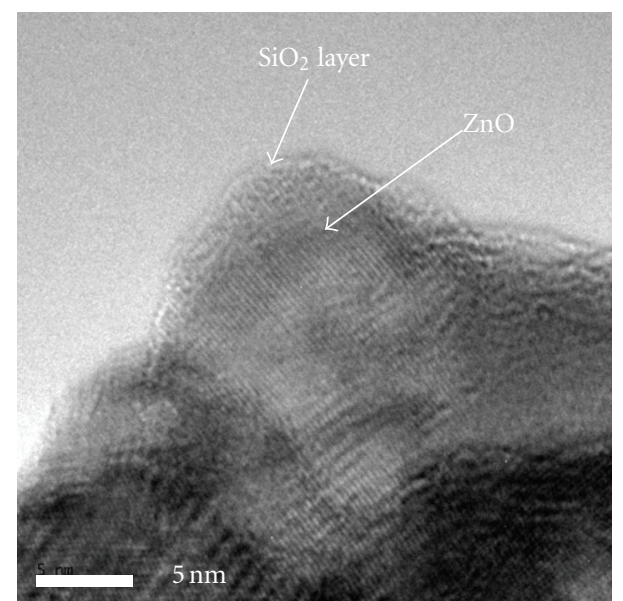

FIgURE 4: An FETEM image of the $\mathrm{SiO}_{2}$-coated $\mathrm{ZnO}$ particles [2].

is concerned, at least 12 types of crystal structures are known [34]. In our case [3], the $\mathrm{Nb}_{2} \mathrm{O}_{5}$ coating layer derived from the $\left(\mathrm{C}_{2} \mathrm{H}_{5} \mathrm{O}\right)_{5} \mathrm{Nb}$ solution was supposed to be the TT phase which could be classified as the quasi-hexagonal crystal system. Figure 3(b) compares XPS spectra in the $\mathrm{Nb} 3 \mathrm{~d}$ region for the uncoated and the $\mathrm{Nb}_{2} \mathrm{O}_{5}$-coated $\mathrm{ZnO}$ films. No peak is seen for the uncoated $\mathrm{ZnO}$ film, whereas the $\mathrm{Nb}$ $3 \mathrm{~d}_{3 / 2}$ and $3 \mathrm{~d}_{5 / 2}$ peaks appear at 209.5 and $207.0 \mathrm{eV}$, respectively, for all the $\mathrm{Nb}_{2} \mathrm{O}_{5}$-coated $\mathrm{ZnO}$ films. The presence of niobium in the films is, thus, confirmed and the formation of the $\mathrm{Nb}_{2} \mathrm{O}_{5}$ coating layer is supported. Unfortunately, the $\mathrm{Nb}_{2} \mathrm{O}_{5}$ coating layers could not be observed directly by FETEM because the $\mathrm{ZnO}$ particles were decomposed by an electron beam accelerated at high voltage. In turn, an additional effect of the coatings was found in the TEM observation. Figure 5(a) shows a TEM image of the $\mathrm{ZnO}$ particles of the uncoated film which was used as the coating target. $\mathrm{ZnO}$ nanoparticles around $20 \mathrm{~nm}$ in size are clearly observed. When the uncoated $\mathrm{ZnO}$ film is heated at $600^{\circ} \mathrm{C}$ for $10 \mathrm{~min}$, the growth of the $\mathrm{ZnO}$ particles was promoted and the particle size was increased up to more than $50 \mathrm{~nm}$ (Figure 5(b)). On the other hand, the growth of both the $\mathrm{SiO}_{2}$ - and the $\mathrm{Nb}_{2} \mathrm{O}_{5}$-coated $\mathrm{ZnO}$ particles is hindered even after heating at $600^{\circ} \mathrm{C}$, and the particle size is kept around $20 \mathrm{~nm}$ (Figures 5(c)-5(f)). These results imply that the nanocoating layers actually exist on the surface of the $\mathrm{ZnO}$ particles and disturb the mass transport related to the grain growth or sintering during heating. Accordingly, the $\mathrm{SiO}_{2}$ and the $\mathrm{Nb}_{2} \mathrm{O}_{5}$ nanocoatings are successfully formed on the $\mathrm{ZnO}$ electrodes. In the XRD analysis, diffraction peaks due to $\mathrm{ZnO}$ did not show any shift after the $\mathrm{SiO}_{2}$ and $\mathrm{Nb}_{2} \mathrm{O}_{5}$ coating process, indicating that the lattice strain due to doping or stress was negligible for discussing the coating effect.

3.2. Structure of $\mathrm{TiO}_{2}$ - and $\mathrm{ZrO}_{2}$-Coated $\mathrm{ZnO}$ Films. To know crystal phases of $\mathrm{TiO}_{2}$ and $\mathrm{ZrO}_{2}$ coating layers, we characterized first as-prepared and heat-treated gels which were 


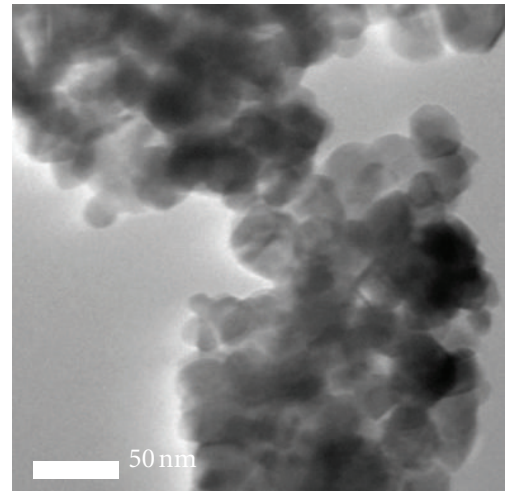

(a)

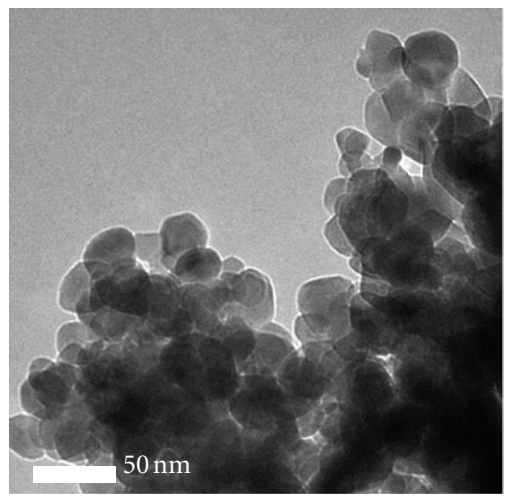

(d)

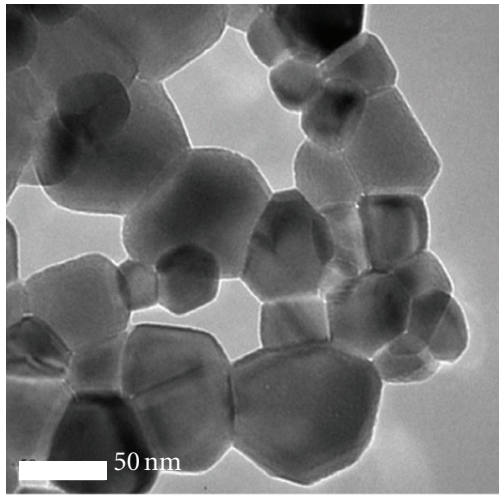

(b)

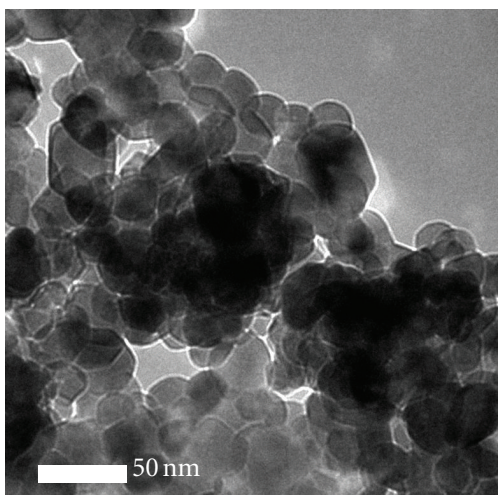

(e)

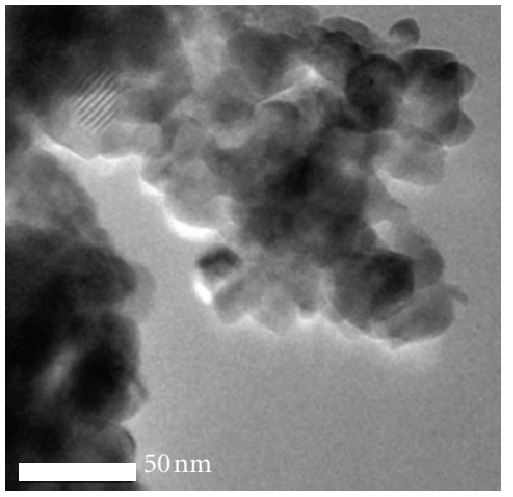

(c)

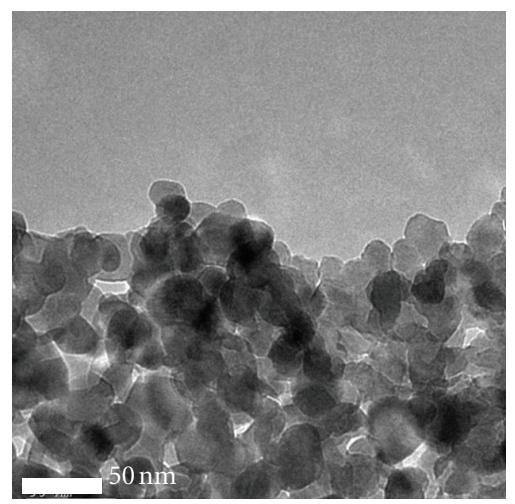

(f)

FIgURE 5: FETEM images of (a) the uncoated, (b) the uncoated/heated, (c) the $\mathrm{SiO}_{2}$-coated films, and the films coated with (d) $10 \mathrm{mM}$, (e) $20 \mathrm{mM}$, and (f) $30 \mathrm{mM}$ of the $\left(\mathrm{C}_{2} \mathrm{H}_{5} \mathrm{O}\right)_{5} \mathrm{Nb}$ solutions $[2,3]$.

obtained by forced hydrolysis of $\left[\left(\mathrm{CH}_{3}\right)_{2} \mathrm{CHO}\right]_{4} \mathrm{Ti}$ in ethanol and $\left(\mathrm{C}_{3} \mathrm{H}_{7} \mathrm{O}\right)_{4} \mathrm{Zr}$ in 1-propanol by adding water. XRD patterns of the as-prepared and the heated titanium oxide gels are shown in Figure 6(a). The as-prepared titanium oxide gel is amorphous, whereas the gel heated at $600^{\circ} \mathrm{C}$ is a mixture of anatase and brookite phases of $\mathrm{TiO}_{2}$. The as-prepared zirconium oxide gel is also amorphous, and a crystalline phase is observed for the gel heated at $600^{\circ} \mathrm{C}$ (Figure 6(b)) with XRD peaks originating from tetragonal or cubic $\mathrm{ZrO}_{2}$. The heated gel was further analyzed by Fourier transform infrared (FT-IR) spectroscopy (data not shown). The result showed that a band related to the tetragonal $\mathrm{ZrO}_{2}$ was detected at $575 \mathrm{~cm}^{-1}$ [35]. Therefore, the $\mathrm{TiO}_{2}$ and the $\mathrm{ZrO}_{2}$ coating layers, as described below, are regarded as the mixture of anatase- and brookite-type $\mathrm{TiO}_{2}$ and the tetragonal $\mathrm{ZrO}_{2}$, respectively.

For the $\mathrm{TiO}_{2}$ - and the $\mathrm{ZrO}_{2}$ coated $\mathrm{ZnO}$ films, the morphology and the thickness did not change after the coating procedures including subsequent heating. The coated films were examined by XPS to confirm the presence of the $\mathrm{TiO}_{2}$ and the $\mathrm{ZrO}_{2}$ coating layers. Figure 7(a) compares XPS spectra of the uncoated and the $\mathrm{TiO}_{2}$-coated $\mathrm{ZnO}$ films. For the $\mathrm{TiO}_{2}(20 \mathrm{mM})$-coated and the $\mathrm{TiO}_{2}(30 \mathrm{mM})$-coated $\mathrm{ZnO}$ film, a Ti $2 \mathrm{p}_{1 / 2}$ peak can be observed at $458.6 \mathrm{eV}$.
Figure 7(b) compares XPS spectra of the uncoated and the $\mathrm{ZrO}_{2}$-coated $\mathrm{ZnO}$ films. While no peak is seen for the uncoated $\mathrm{ZnO}$ film, two peaks appear in all the spectra for the coated films at approximately $184.4 \mathrm{eV}$ and $182.0 \mathrm{eV}$, corresponding to the binding energy of $\mathrm{Zr} 3 \mathrm{~d}_{3 / 2}$ and $3 \mathrm{~d}_{5 / 2}$ electrons, respectively. The XPS results suggest that the $\mathrm{ZrO}_{2}$ coating layers are formed on the $\mathrm{ZnO}$ particles regardless of the $\left(\mathrm{C}_{3} \mathrm{H}_{7} \mathrm{O}\right)_{4} \mathrm{Zr}$ concentration, whereas the $\mathrm{TiO}_{2}$ coating layers are formed at least in the $\mathrm{TiO}_{2}(20 \mathrm{mM})$-coated and the $\mathrm{TiO}_{2}(30 \mathrm{mM})$-coated film.

The formation of the $\mathrm{TiO}_{2}$ and the $\mathrm{ZrO}_{2}$ coating layers could not be observed by FETEM, for the same reason as mentioned above. Then we tried to see the hindrance of the grain growth. Low magnification TEM images of the $\mathrm{TiO}_{2}$ - and the $\mathrm{ZrO}_{2}$-coated $\mathrm{ZnO}$ films is shown in Figure 8. Compared to the uncoated/heated $\mathrm{ZnO}$ particles shown in Figure 5(b), the size of the $\mathrm{TiO}_{2}$ - and the $\mathrm{ZrO}_{2}$-coated $\mathrm{ZnO}$ particles are smaller, indicative of the hindrance effect. The $\mathrm{TiO}_{2}$ and the $\mathrm{ZrO}_{2}$ coating layers are then suggested to be formed on the $\mathrm{ZnO}$ particles, as in the case of the $\mathrm{SiO}_{2}$ and the $\mathrm{Nb}_{2} \mathrm{O}_{5}$ coating.

It should be noted that the size of the $\mathrm{TiO}_{2}$ - and the $\mathrm{ZrO}_{2}$-coated $\mathrm{ZnO}$ particles appears to be slightly larger than that of the $\mathrm{SiO}_{2}$ - and the $\mathrm{Nb}_{2} \mathrm{O}_{5}$-coated particles. The 


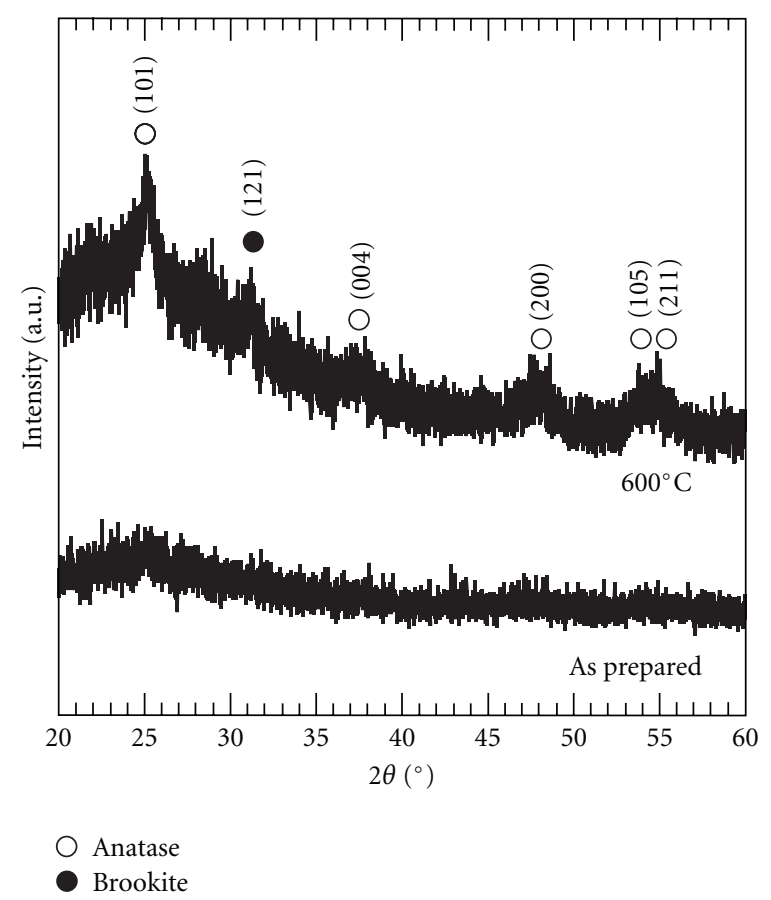

(a)

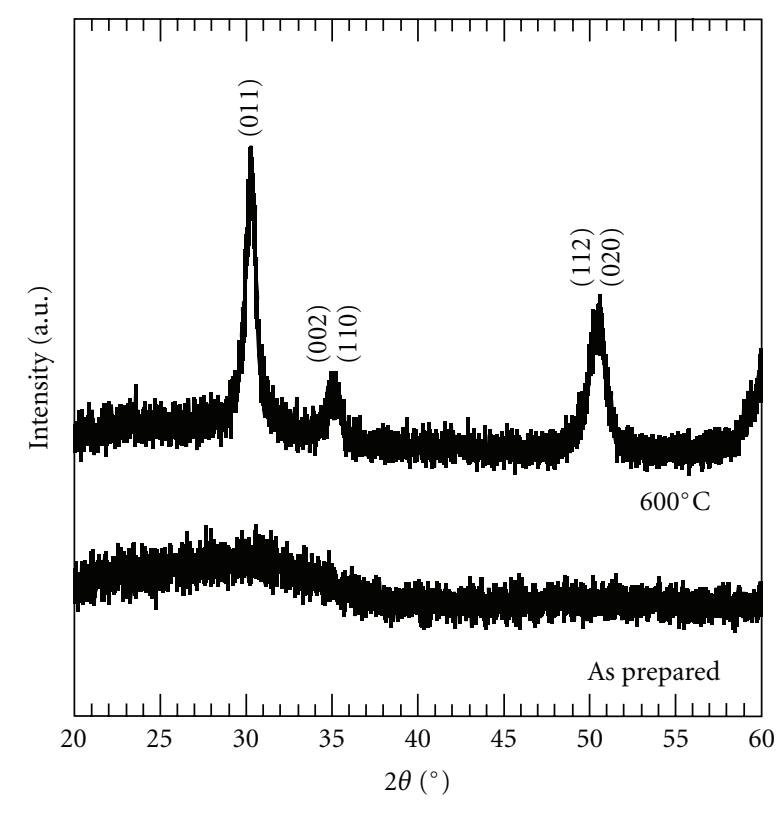

(b)

FIGURE 6: XRD patterns of (a) the as-prepared and the heated titanium oxide gel and (b) the as-prepared and the heated zirconium oxide gel.

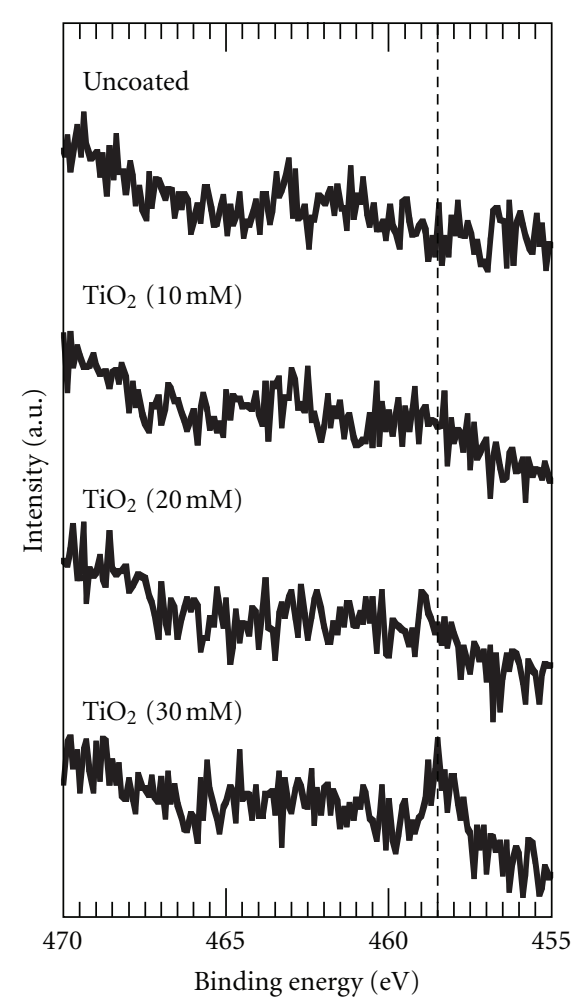

(a)

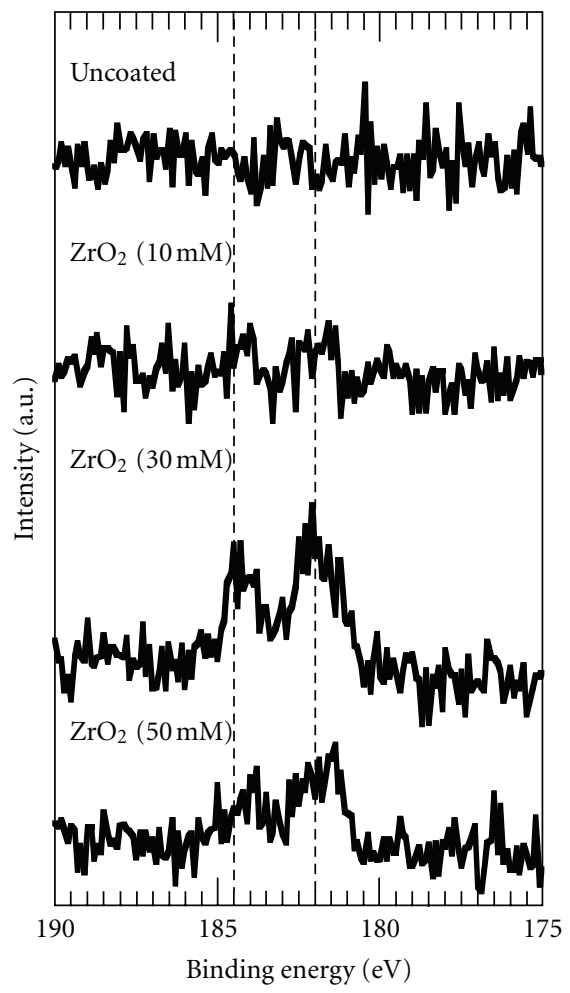

(b)

FIgURE 7: XPS spectra (a) in the Ti $2 \mathrm{p}$ region for the uncoated and the $\mathrm{TiO}_{2}$-coated electrodes and (b) in the $\mathrm{Zr} 3 \mathrm{~d}$ region for the uncoated and the $\mathrm{ZrO}_{2}$-coated electrodes. 


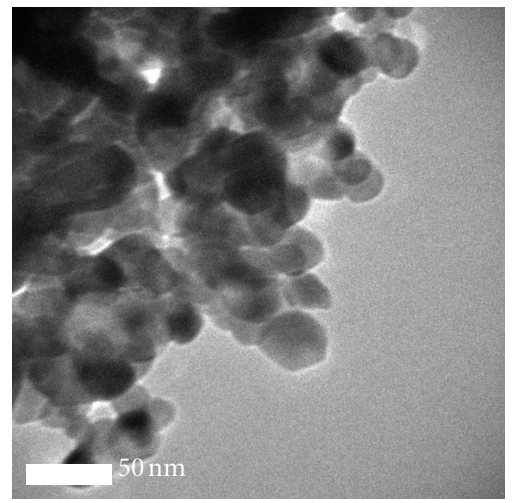

(a)

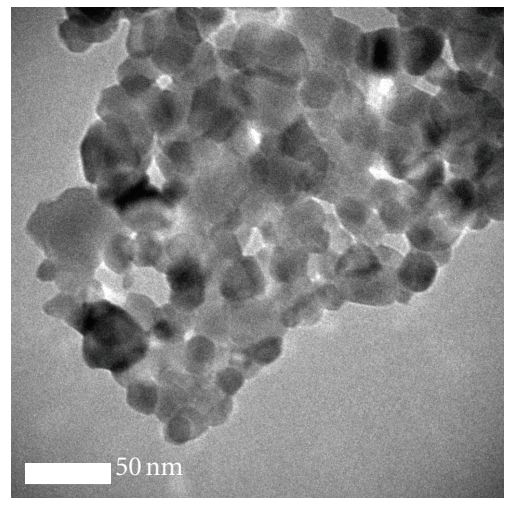

(d)

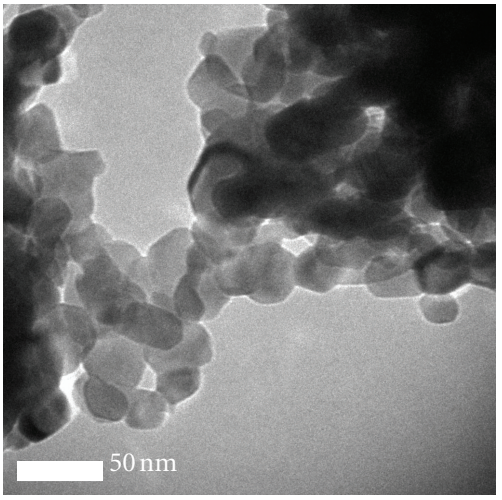

(b)

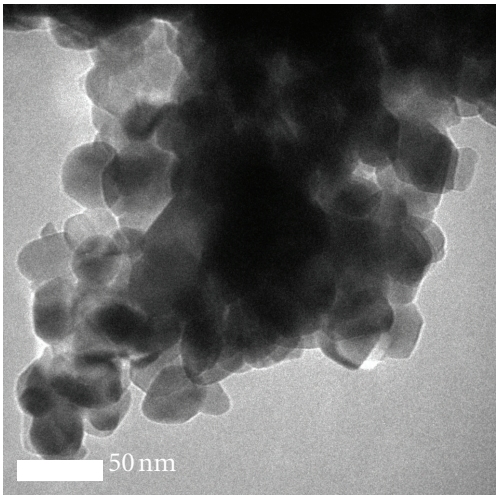

(e)

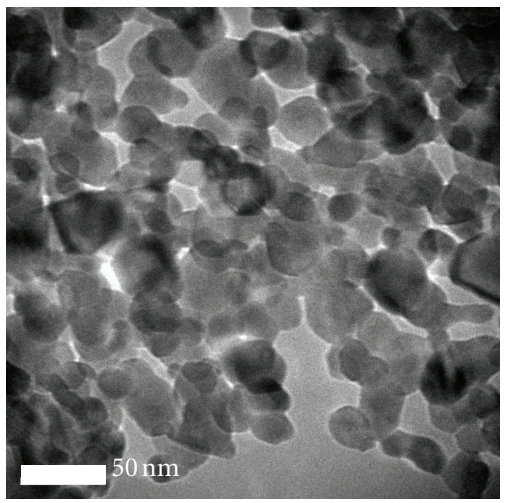

(c)

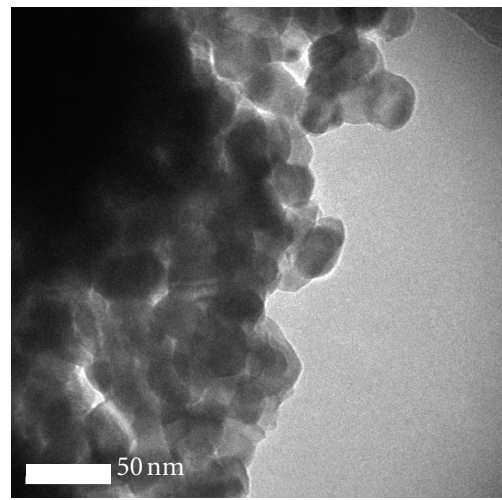

(f)

FIGURE 8: FETEM images of the films coated with (a) $10 \mathrm{mM}$, (b) $20 \mathrm{mM}$, and (c) $30 \mathrm{mM}$ of the $\left[\left(\mathrm{CH}_{3}\right)_{2} \mathrm{CHO}\right]_{4} \mathrm{Ti}$ solutions and the films coated with (d) $10 \mathrm{mM}$, (e) $30 \mathrm{mM}$, and (f) $50 \mathrm{mM}$ of the $\left(\mathrm{C}_{3} \mathrm{H}_{7} \mathrm{O}\right)_{4} \mathrm{Zr}$ solutions.

Scherrer diameter of the uncoated and all the coated $\mathrm{ZnO}$ films was evaluated quantitatively from the XRD data by using the following Scherrer equation [36]:

$$
D=\frac{0.9 \lambda}{\beta \cos \theta},
$$

where $\lambda$ is the wavelength of the $\mathrm{X}$-ray irradiation $(\mathrm{CuK} \alpha=$ $1.5418 \AA$ ), $\beta$ is the full width of half maximum (FWHM) of the peak, and $\theta$ is the diffraction angle. Figure 9 compares the Scherrer diameters calculated for the (100), (002), and (101) peaks of $\mathrm{ZnO}$. In Figure 9(a), the Scherrer diameters of the $\mathrm{SiO}_{2}$ - and the $\mathrm{Nb}_{2} \mathrm{O}_{5}$-coated $\mathrm{ZnO}$ particles are approximately the same as that of the uncoated $\mathrm{ZnO}$ (around $21 \mathrm{~nm}$ ). In contrast, for the uncoated/heated $\mathrm{ZnO}$, the Scherrer diameter increases up to $35 \mathrm{~nm}$ due to the grain growth by heating. The $\mathrm{TiO}_{2}$ - and the $\mathrm{ZrO}_{2}$-coated $\mathrm{ZnO}$ particles show the larger diameters than that of the uncoated $\mathrm{ZnO}$ particles (Figure 9(b)), indicating that the hindrance of the grain growth is less effective for the $\mathrm{TiO}_{2}$ and the $\mathrm{ZrO}_{2}$ coating. There are two possible reasons for such the difference between the coating materials. Firstly, the ability to suppress the grain growth of $\mathrm{ZnO}$ may be peculiar for a certain kind of metal oxides. Secondly, the surface coverage of the coating layers formed by the sol-gel transformation is different among the respective metal oxides. The hindrance of the $\mathrm{ZnO}$ grain growth arises from disturbing the mass transportation by the coating layers, which means that the latter reason is more probable. That is, the coating layers on the $\mathrm{ZnO}$ particles with the lower surface coverage allow the grain growth to occur more rapidly by heating. Actually, the Scherrer diameter of the $\mathrm{TiO}_{2}$ - and the $\mathrm{ZrO}_{2}$-coated $\mathrm{ZnO}$ decreases with the concentration of the metal alkoxides in the coating solutions (Figure 9(b)). This fact is consistent with the basics of the dip-coating method; the thickness and the surface coverage of the coating layers depend directly on the concentration of the metal source. The XPS results also suggested the lower surface coverage for the films coated with the lower concentration of the coating solutions. Hence, we tentatively conclude that the increase in the Scherrer diameter for the $\mathrm{TiO}_{2}$ - and the $\mathrm{ZrO}_{2}$-coated $\mathrm{ZnO}$ particles is attributed to the lower surface coverage of the coating layers, which might be influenced by the kinetics of the solgel transformation. Additionally, the lattice strain of $\mathrm{ZnO}$ due to doping or stress was not found by the coating process as in the case for the $\mathrm{SiO}_{2}$ and $\mathrm{Nb}_{2} \mathrm{O}_{5}$ coating.

3.3. Performance of DSSCs using the Coated Electrodes. The cell performance of DSSCs using the uncoated and the coated $\mathrm{ZnO}$ electrodes was evaluated from the $J-V$ measurements. The characteristic values, $V_{\mathrm{OC}}, J_{\mathrm{SC}}$, ff, and $\eta$, together with the amount of the adsorbed dye, are summarized in Table 1. $J-V$ curves of the uncoated, the uncoated/heated, and the 


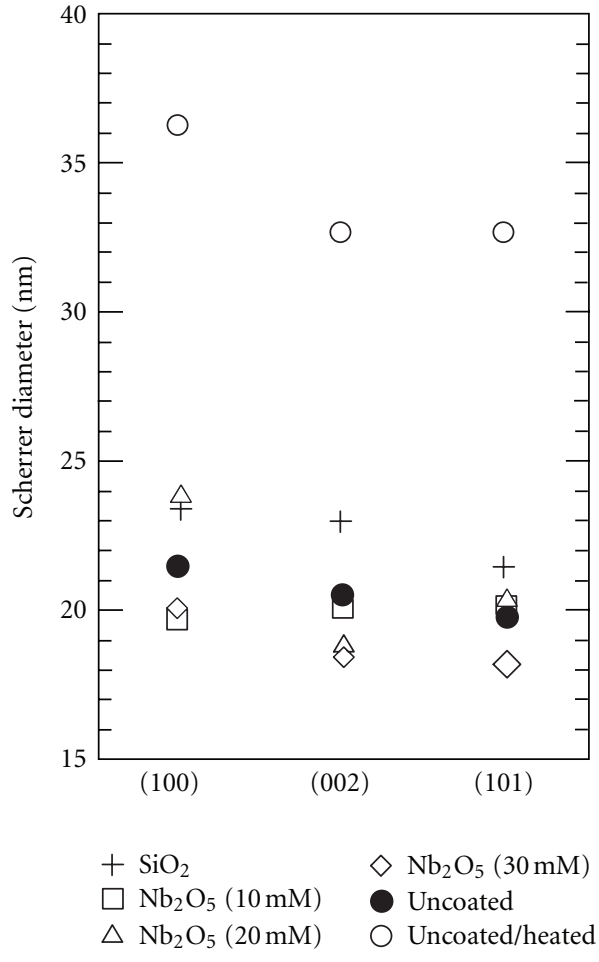

(a)

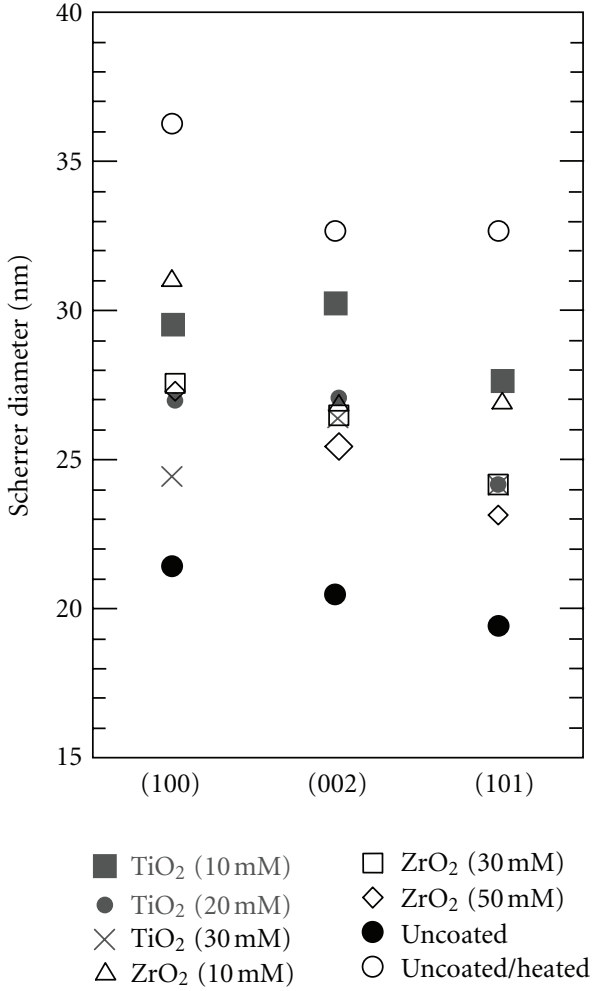

(b)

Figure 9: The Scherrer diameters for (a) the $\mathrm{SiO}_{2}$ - and the $\mathrm{Nb}_{2} \mathrm{O}_{5}$-coated and (b) the $\mathrm{TiO}_{2}$ - and the $\mathrm{ZrO}_{2}$-coated $\mathrm{ZnO}$ films with respect to the (100), (002), and (101) planes of $\mathrm{ZnO}$.

TABLE 1: The cell performance of the DSSCs using the uncoated and the coated $\mathrm{ZnO}$ electrodes $[2,3]$.

\begin{tabular}{|c|c|c|c|c|c|}
\hline Electrode & $V_{\mathrm{OC}}(\mathrm{V})$ & $J_{\mathrm{SC}}\left(\mathrm{mA} \mathrm{cm}^{-2}\right)$ & $\mathrm{ff}(-)$ & $\eta(\%)$ & Dye adsorption $\left(10^{-7} \mathrm{~mol} \mathrm{~cm}^{-2}\right)$ \\
\hline Uncoated & 0.683 & 11.59 & 0.578 & 4.57 & 1.08 \\
\hline Uncoated/heated & 0.718 & 7.11 & 0.535 & 2.73 & 0.55 \\
\hline $\mathrm{SiO}_{2}$ coated & 0.724 & 12.05 & 0.550 & 4.80 & 0.89 \\
\hline $\mathrm{Nb}_{2} \mathrm{O}_{5}(10 \mathrm{mM})$ coated & 0.712 & 12.42 & 0.587 & 5.19 & 0.76 \\
\hline $\mathrm{Nb}_{2} \mathrm{O}_{5}(20 \mathrm{mM})$ coated & 0.741 & 10.67 & 0.549 & 4.34 & 1.12 \\
\hline $\mathrm{Nb}_{2} \mathrm{O}_{5}(30 \mathrm{mM})$ coated & 0.755 & 9.43 & 0.577 & 4.10 & 1.02 \\
\hline $\mathrm{TiO}_{2}(10 \mathrm{mM})$ coated & 0.729 & 9.18 & 0.503 & 3.37 & 0.92 \\
\hline $\mathrm{TiO}_{2}(20 \mathrm{mM})$ coated & 0.730 & 10.01 & 0.512 & 3.74 & 0.92 \\
\hline $\mathrm{TiO}_{2}(30 \mathrm{mM})$ coated & 0.730 & 9.54 & 0.501 & 3.49 & 0.88 \\
\hline $\mathrm{ZrO}_{2}(10 \mathrm{mM})$ coated & 0.765 & 7.71 & 0.570 & 3.36 & 1.01 \\
\hline $\mathrm{ZrO}_{2}(30 \mathrm{mM})$ coated & 0.746 & 9.53 & 0.545 & 3.87 & 1.09 \\
\hline $\mathrm{ZrO}_{2}(50 \mathrm{mM})$ coated & 0.746 & 9.16 & 0.551 & 3.77 & 0.94 \\
\hline
\end{tabular}

$\mathrm{SiO}_{2}$-coated $\mathrm{ZnO}$ electrodes are shown in Figure 10(a). Firstly, the cell performance of the DSSCs using the uncoated and the uncoated/heated electrodes is discussed. The cell using the uncoated $\mathrm{ZnO}$ electrode shows $V_{\mathrm{OC}}$ of $0.683 \mathrm{~V}, J_{\mathrm{SC}}$ of $11.59 \mathrm{~mA} / \mathrm{cm}^{2}$, and conversion efficiency of $4.57 \%$. In the cell using the uncoated/heated electrode, $V_{\mathrm{OC}}$ increases to $0.718 \mathrm{~V}$ while $J_{\mathrm{SC}}$ decreases to $7.11 \mathrm{~mA} / \mathrm{cm}^{2}$. These changes can be explained with the progress of the grain growth during heating [37]. The size of the $\mathrm{ZnO}$ particles heated at $600^{\circ} \mathrm{C}$ for $10 \mathrm{~min}$ increases up to more than $50 \mathrm{~nm}$, leading to the significant decrease in the net surface area of the electrodes. Simultaneously, the recombination sites located at the surface of the $\mathrm{ZnO}$ particles are diminished by the high-temperature heating. Dark current-voltage curves shown in Figure 10(b) reveal that the dark current of the uncoated/heated electrode is much smaller than that of the uncoated electrode at the same bias. This fact also suggests that the recombination is strongly suppressed in 


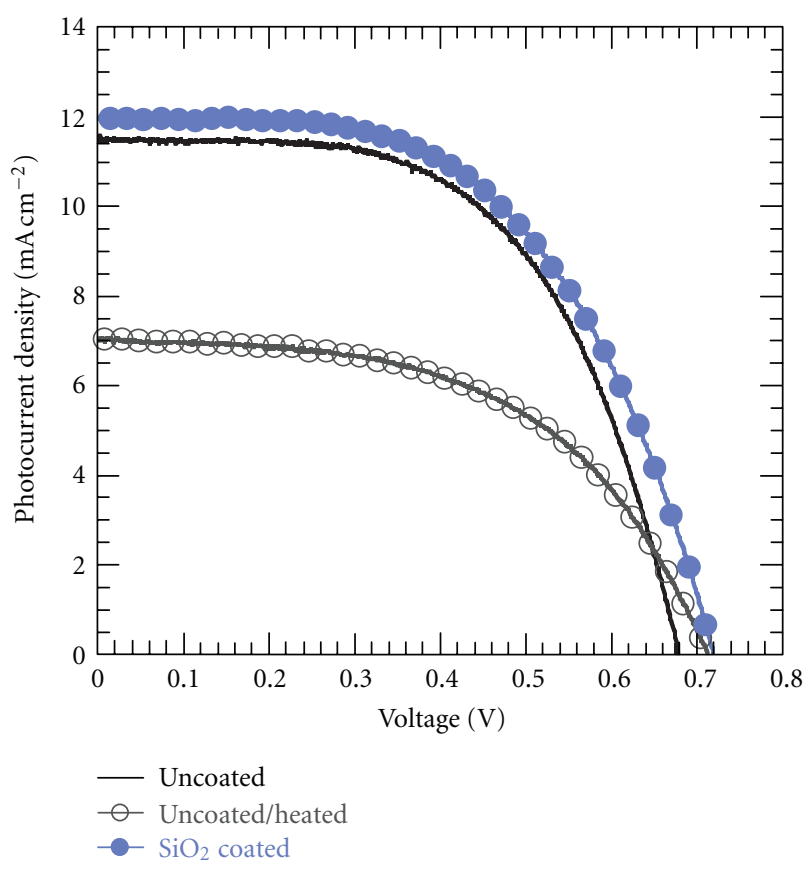

(a)

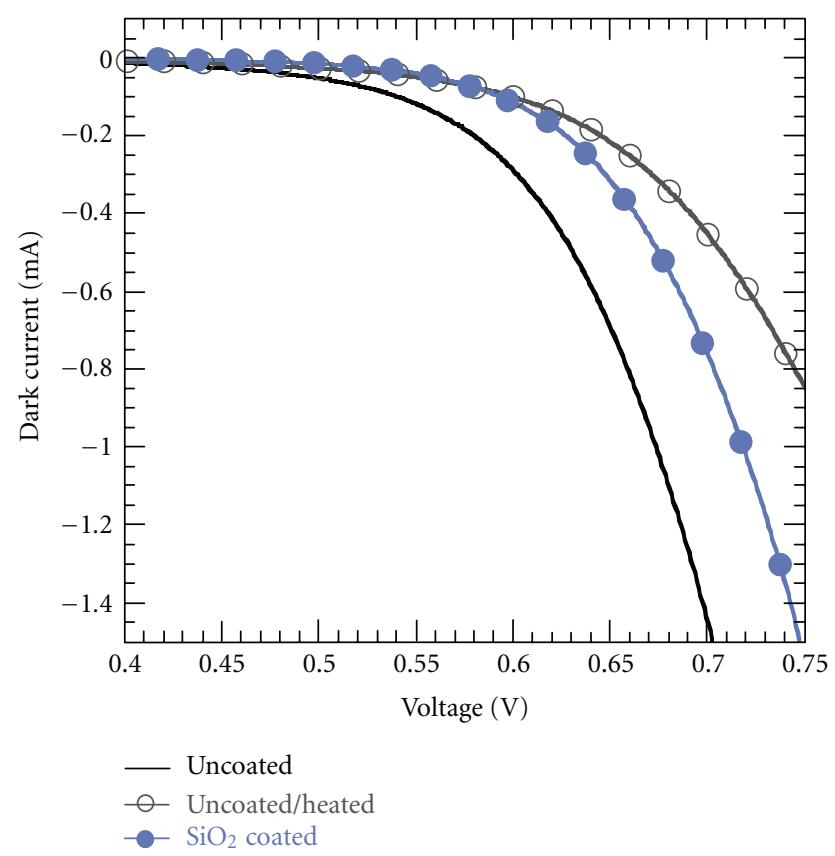

(b)

Figure 10: (a) $J$ - $V$ curves and (b) dark current-voltage curves of the cells using the uncoated, the uncoated/heated, and $\mathrm{SiO}_{2}-\mathrm{coated}_{\mathrm{ZnO}}$ electrodes [2].

the uncoated/heated electrode. Hence, according to (1), the relatively high $V_{\mathrm{OC}}$ is obtained for the cell using the uncoated/heated electrode. On the other hand, the amount of the adsorbed dye decreases by half with the decrease in the surface area of the electrode, resulting in the significantly lowered $J_{\mathrm{SC}}$. As a result, the energy conversion efficiency of the cells using the uncoated $\mathrm{ZnO}$ electrodes decreases from $4.57 \%$ to $2.73 \%$ by heating.

In the cell using the $\mathrm{SiO}_{2}$-coated electrode, $V_{\mathrm{OC}}$ and $J_{\text {SC }}$ increase to $0.724 \mathrm{~V}$ and $12.05 \mathrm{~mA} / \mathrm{cm}^{2}$, respectively, even after heating at $600^{\circ} \mathrm{C}[2]$. The particle size does not change by heating due to the hindrance of the grain growth by the formation of the $\mathrm{SiO}_{2}$ nanocoating layer on the $\mathrm{ZnO}$ particles. Therefore, the enhancement of the cell performance is attributed not to the decrease in the net surface area of the electrode but to the suppression of the recombination by constructing the energy barrier at the $\mathrm{ZnO}$ /electrolyte interface. The presence of the energy barrier is also suggested strongly by the smaller dark current of the $\mathrm{SiO}_{2}$-coated electrode compared to that of the uncoated electrode at the same bias (Figure 10(b)). $E_{\text {Св }}$ of $\mathrm{SiO}_{2}$ is located at $-0.20 \mathrm{eV}$ versus $E_{\mathrm{VAC}}$, which is approximately $4.0 \mathrm{eV}$ above $E_{\mathrm{CB}}$ of $\mathrm{ZnO}$, and this energy difference works as the barrier for the recombination [38]. Additionally, as the decrease in the surface area of the electrode can be avoided by the hindrance of the grain growth, the amount of the adsorbed dye for the $\mathrm{SiO}_{2}$-coated electrode is comparable to that for the uncoated electrode. Both the suppression of the recombination and the hindrance of the grain growth by the $\mathrm{SiO}_{2}$ coating layer contribute to the enhancement in $J_{\mathrm{SC}}$. Due to the increase in $V_{\mathrm{OC}}$ and $J_{\mathrm{SC}}$, the $\mathrm{SiO}_{2}$-coated $\mathrm{ZnO}$ electrode exhibits higher-energy conversion efficiency of $4.80 \%$. This result demonstrates that even the insulator coatings are effective to improve the cell performance including $J_{\mathrm{SC}}$. Since $E_{\mathrm{CB}}$ of $\mathrm{SiO}_{2}$ is located at higher energy level than the $S^{*}$ state of N719 (approximately $3.65 \mathrm{eV}$ above) [39], the electron injection may be retarded considerably. In the present case, the electron injection to the $\mathrm{SiO}_{2}$-coated $\mathrm{ZnO}$ might be possible from the dye adsorbed on the "bare" $\mathrm{ZnO}$ surface rather than the tunneling effect because the thickness of the $\mathrm{SiO}_{2}$ coating layer $(1-3 \mathrm{~nm})$ is too large.

Contrary to $\mathrm{SiO}_{2}, E_{\mathrm{CB}}$ of $\mathrm{Nb}_{2} \mathrm{O}_{5}$ is located approximately $0.2 \mathrm{eV}$ above $E_{\mathrm{CB}}$ of $\mathrm{ZnO}$ and $0.3 \mathrm{eV}$ below the $S^{*}$ state of N719 $[39,40]$. Therefore, the $\mathrm{Nb}_{2} \mathrm{O}_{5}$-coating would not disturb the electron injection when they act as the energy barrier for the recombination [27]. $J-V$ curves and dark current-voltage curves of the uncoated and the $\mathrm{Nb}_{2} \mathrm{O}_{5}$ coated $\mathrm{ZnO}$ electrodes are shown in Figure 11. As mentioned above, the hindrance effect of the grain growth is found in all the $\mathrm{Nb}_{2} \mathrm{O}_{5}$-coated electrodes. Higher $V_{\mathrm{OC}}$ for the $\mathrm{Nb}_{2} \mathrm{O}_{5^{-}}$ coated electrodes is then ascribed to the suppression of the recombination by the $\mathrm{Nb}_{2} \mathrm{O}_{5}$ coating layers. In addition, as can be seen in Figure 11(a) and Table 1, $V_{\mathrm{OC}}$ of the cells using the $\mathrm{Nb}_{2} \mathrm{O}_{5}$-coated $\mathrm{ZnO}$ electrodes increases from 0.712 to $0.755 \mathrm{~V}$ when the $\left(\mathrm{C}_{2} \mathrm{H}_{5} \mathrm{O}\right)_{5} \mathrm{Nb}$ concentration increases from 10 to $30 \mathrm{mM}$. This tendency of the $V_{\mathrm{OC}}$ increase may be due to the increase in the surface coverage of the $\mathrm{Nb}_{2} \mathrm{O}_{5}$ coating layers which work as the energy barrier for the recombination. In fact, as found in Figure 11(b), the dark current of the $\mathrm{Nb}_{2} \mathrm{O}_{5}$-coated electrodes decreases with the $\left(\mathrm{C}_{2} \mathrm{H}_{5} \mathrm{O}\right)_{5} \mathrm{Nb}$ concentration. Especially for the $\mathrm{Nb}_{2} \mathrm{O}_{5}$ $(30 \mathrm{mM})$-coated electrode, the dark current is as small as that 


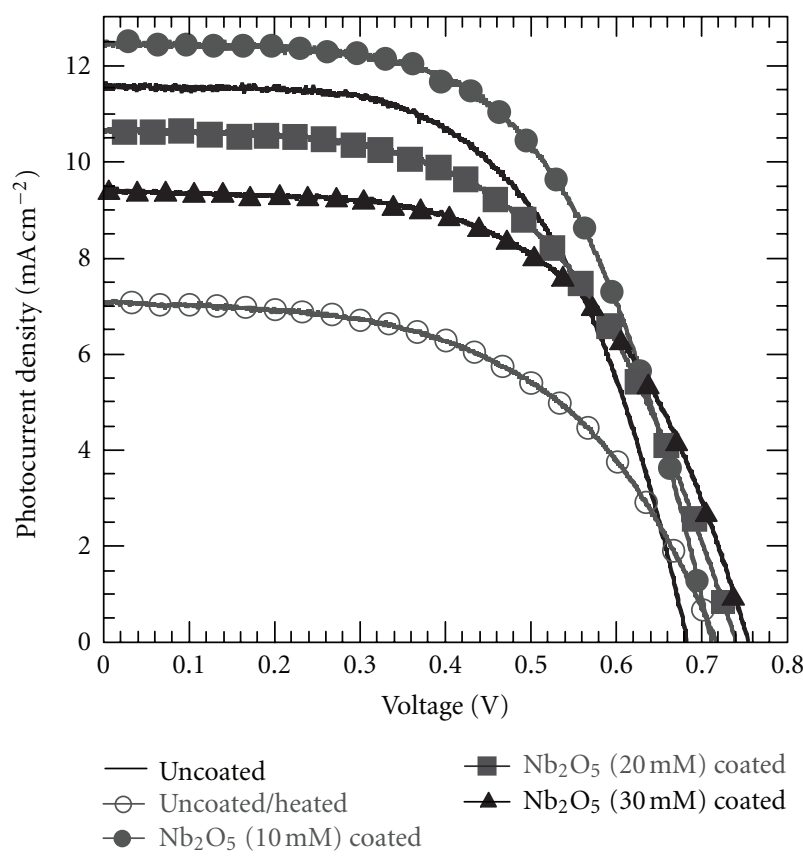

(a)

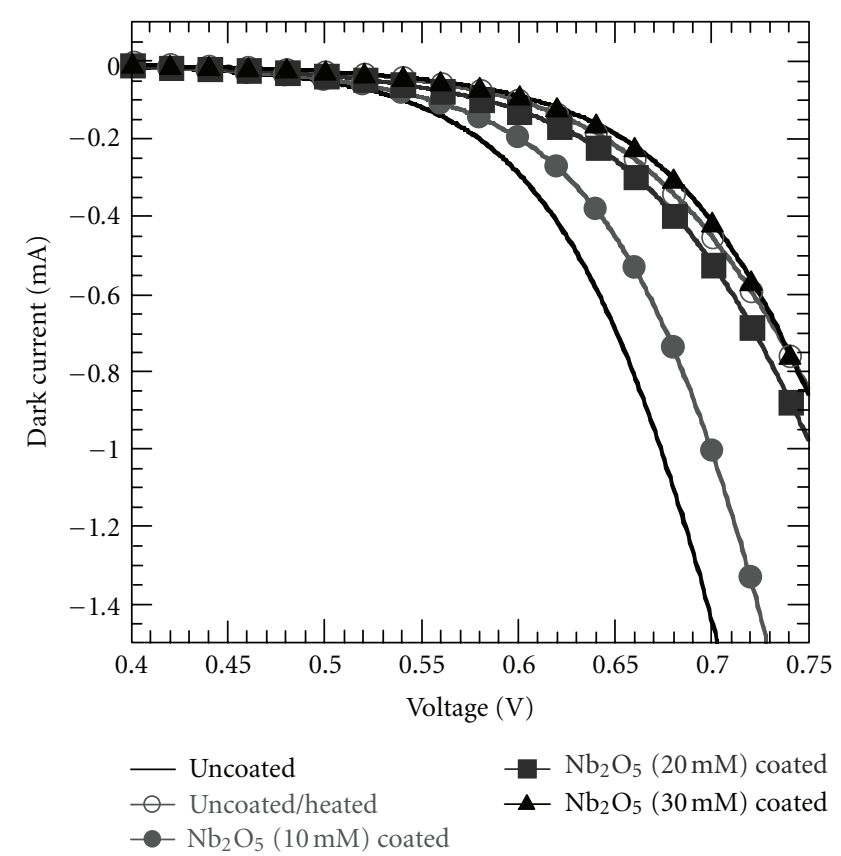

(b)

FIgURE 11: (a) $J-V$ curves and (b) dark current-voltage curves of the cells using the uncoated, the uncoated/heated, and the $\mathrm{Nb}_{2} \mathrm{O}_{5}-\mathrm{coated}$ $\mathrm{ZnO}$ electrodes [3].

of the uncoated/heated electrode. This is probably because of the higher surface coverage of $\mathrm{Nb}_{2} \mathrm{O}_{5}$.

$J_{\mathrm{SC}}$ of the $\mathrm{Nb}_{2} \mathrm{O}_{5}$-coated electrodes, on the other hand, tends to decrease with the coating solution concentration. This is attributable to the lower electron conductivity of the $\mathrm{Nb}_{2} \mathrm{O}_{5}$ coating layers [34], judging from the fact that the dye adsorption ability is not changed by the coating. It is also reported that the charge injection efficiency from the $\mathrm{Ru}(\mathrm{II})$ complex dye to $\mathrm{Nb}_{2} \mathrm{O}_{5}$ is similar to that to $\mathrm{ZnO}$ [41]. The thicker coating layer with the higher coverage can possibly disturb the electron transport inside the electrode and decrease $J_{S C}$ to some extent. For the $\mathrm{Nb}_{2} \mathrm{O}_{5}(10 \mathrm{mM})$ coated $\mathrm{ZnO}$ electrode, since both $V_{\mathrm{OC}}$ and $J_{\mathrm{SC}}$ are improved due to the efficient suppression of the recombination and the hindrance of the grain growth, the higher energy conversion efficiency of $5.19 \%$ has been achieved. These results suggest that $\mathrm{Nb}_{2} \mathrm{O}_{5}$ is more suitable for coating on the $\mathrm{ZnO}$ electrodes than $\mathrm{SiO}_{2}$.

In the case of the $\mathrm{Nb}_{2} \mathrm{O}_{5}$ coating, the $\mathrm{ZnO}$ particle size is kept constant (around $20 \mathrm{~nm}$ ) regardless of the coating solution concentration. Only the structure of the coating layers is concerned. However, for the $\mathrm{TiO}_{2}$ and the $\mathrm{ZrO}_{2}$ coating, we need to consider both the structure of the coating layers and the influence of the grain growth. It is reported that $E_{\mathrm{CB}}$ of $\mathrm{TiO}_{2}$ is approximately 0-200 meV below $E_{\mathrm{CB}}$ of $\mathrm{ZnO}$, and hence the $\mathrm{TiO}_{2}$ coating layers do not work as the energy barrier for the recombination. Actually, however, slight increase in $V_{\mathrm{OC}}$ is found in the cell using the $\mathrm{TiO}_{2}$-coated $\mathrm{ZnO}$ electrodes. As shown in Figure 12(a), the dark current of all the $\mathrm{TiO}_{2}$-coated electrodes is as small as that of the uncoated/heated $\mathrm{ZnO}$ electrode. According to Figure $9(\mathrm{~b})$, the size of the $\mathrm{TiO}_{2}$-coated $\mathrm{ZnO}$ particles slightly increases by heating, which contributes to the increase in $V_{\mathrm{OC}}$ by the reduction of the recombination sites. Considering that the $\mathrm{TiO}_{2}$-coated $\mathrm{ZnO}$ particles are smaller than the uncoated/heated $\mathrm{ZnO}$, the increased $V_{\text {OC }}$ should be explained with the other factor than the grain growth. In other words, the $\mathrm{TiO}_{2}$ coating layer is capable of acting as the energy barrier against our prediction. Actually, there are some reports on the successful $\mathrm{TiO}_{2}$ coatings for improving the performance of DSSCs using $\mathrm{ZnO}$ electrodes [42, 43]. The enhancement in $V_{\mathrm{OC}}$ is ascribed to the passivation of the surface defects of the $\mathrm{ZnO}$ by $\mathrm{TiO}_{2}$. As a result, the recombination from the $\mathrm{ZnO}$ layer is reduced [44]. Further investigations are necessary for $\mathrm{TiO}_{2}$ to clarify the effect or the mechanism of the coating layers.

The decrease in the amount of the adsorbed dye results in the slightly smaller $J_{S C}$ due to the decrease in the surface area by the slight grain growth of the $\mathrm{TiO}_{2}$-coated $\mathrm{ZnO}$ particles. Additionally, the ff values for all the cells using $\mathrm{TiO}_{2}$-coated $\mathrm{ZnO}$ electrode are remarkably smaller than those of the other electrodes. The decrease in $\mathrm{ff}$ is explained with a high intrinsic resistance of the cell [45]. In the present case, the electron transport may be disturbed through the $\mathrm{TiO}_{2}$ coated $\mathrm{ZnO}$ particles inside the electrodes due to the small difference in $E_{\mathrm{CB}}$.

$\mathrm{ZrO}_{2}$ is also considered to work as the energy barrier. Similar to $\mathrm{SiO}_{2}, E_{\mathrm{CB}}$ of $\mathrm{ZrO}_{2}$ is located at $-3.44 \mathrm{eV}$ versus $E_{\mathrm{VAC}}$, which is approximately $0.9 \mathrm{eV}$ above $E_{\mathrm{CB}}$ of $\mathrm{ZnO}$ and $0.4 \mathrm{eV}$ above the $S^{*}$ state of N719 $[38,39]$. The $\mathrm{ZrO}_{2}$ $(10 \mathrm{mM})$-coated electrode exhibits the highest $V_{\mathrm{OC}}$ value of $0.765 \mathrm{~V}$, which is comparable to that of the $\mathrm{TiO}_{2}$-base 


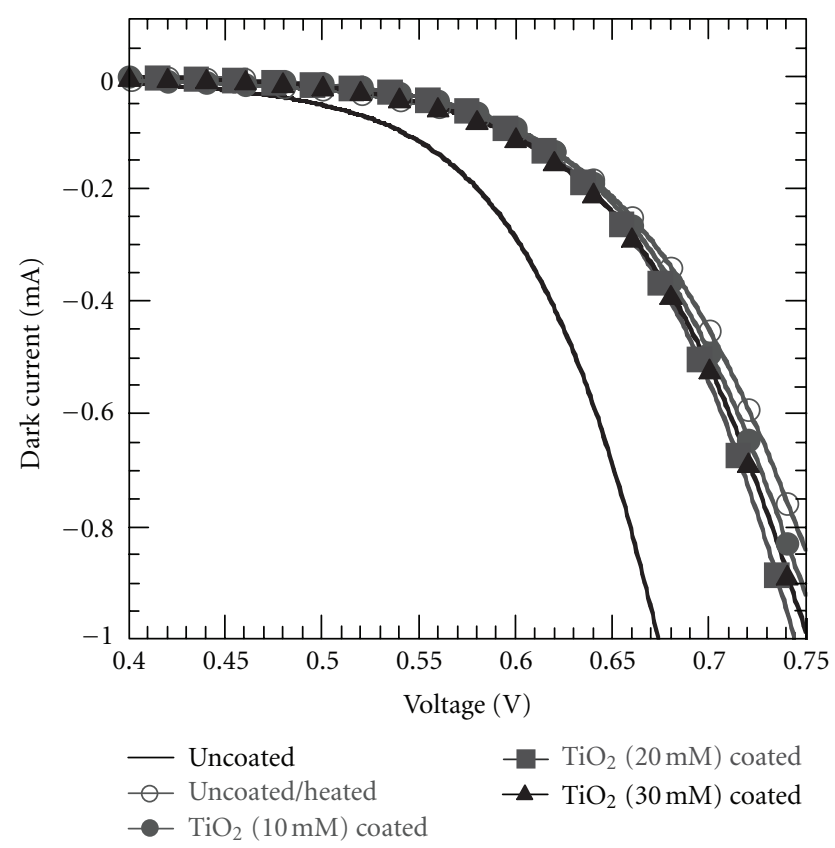

(a)

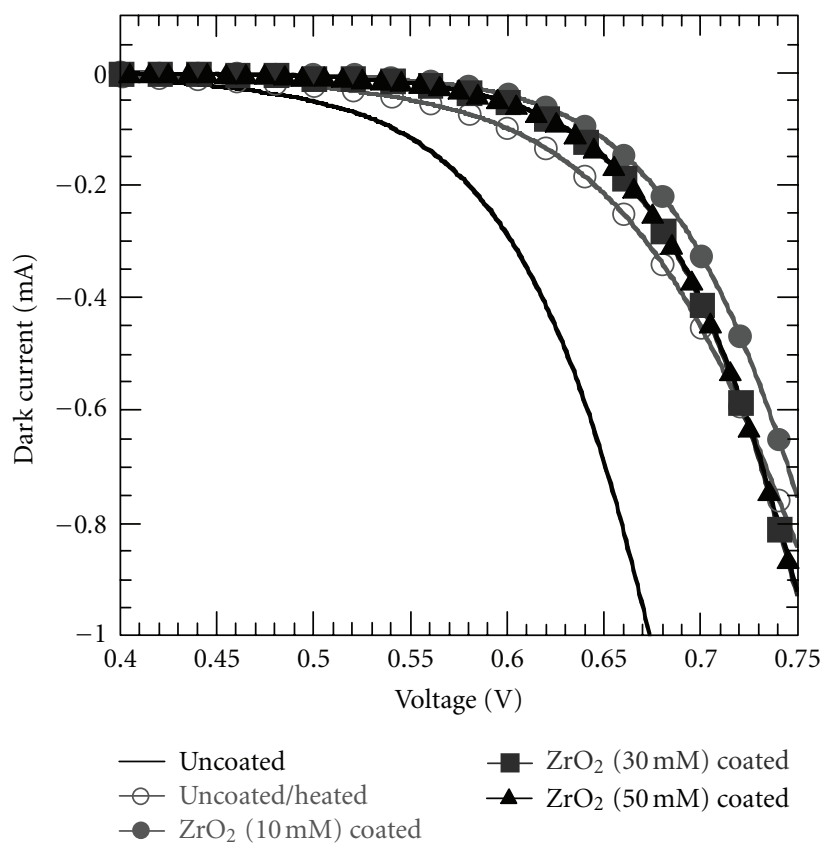

(b)

FIGURE 12: Dark current-voltage curves of the cells using (a) the uncoated, the uncoated/heated, and the $\mathrm{TiO}_{2}$-coated $\mathrm{ZnO}$ electrodes and (b) the uncoated, the uncoated/heated, and the $\mathrm{ZrO}_{2}$-coated $\mathrm{ZnO}$ electrodes.

DSSCs. The coverage of the $\mathrm{ZrO}_{2}$ coating layer is considered to be small because the hindrance of the $\mathrm{ZnO}$ grain growth is less effective for the $\mathrm{ZrO}_{2}$ coating (Figure 9(b)). In particular, the recorded dark current of the $\mathrm{ZrO}_{2}(10 \mathrm{mM})$ coated electrode is smaller than that of the uncoated/heated electrode (Figure 12(b)). This result also suggests that both the reduction of the surface recombination sites due to grain growth and the energy barrier constructed by the $\mathrm{ZrO}_{2}$ coating contribute to the increase in $V_{\mathrm{OC}}$. It is found that $V_{\mathrm{OC}}$ decreases when the $\mathrm{ZnO}$ electrodes are coated with 30 and $50 \mathrm{mM}\left(\mathrm{C}_{3} \mathrm{H}_{7} \mathrm{O}\right)_{4} \mathrm{Zr}$ solutions. This is because the influence of the decrease in the recombination sites on $V_{\mathrm{OC}}$ is diminished by the hindrance of the grain growth due to the higher coverage of the $\mathrm{ZrO}_{2}$ coating. All the $\mathrm{ZrO}_{2}$ coated electrodes show lower $J_{\mathrm{SC}}$ than that of the uncoated electrode. As the amount of the adsorbed dye does not change significantly after the $\mathrm{ZrO}_{2}$ coating, the decrease in $J_{S C}$ is due mainly to the interruption of the electron injection. As a result, the energy conversion efficiency of the cells slightly decreases by the $\mathrm{ZrO}_{2}$ coating.

In this paper, the formation of metal-oxide nanocoatings on $\mathrm{ZnO}$ is demonstrated to be one of the promising approaches to the enhancement of the cell performance. Since $V_{\mathrm{OC}}$ of the cells using the coated $\mathrm{ZnO}$ electrodes depends both on the structure of the metal-oxide coating layers and the structure of the $\mathrm{ZnO}$ electrode itself, we should control carefully the sol-gel transformation conditions and the following heat treatments. We are now trying to form the ultrathin coating layers which suppress more effectively the recombination and enhance the performance of the $\mathrm{ZnO}$ based DSSCs.

\section{Conclusions}

The nanoscale coating of four kinds of metal oxides $\left(\mathrm{SiO}_{2}\right.$, $\mathrm{Nb}_{2} \mathrm{O}_{5}, \mathrm{TiO}_{2}$, and $\mathrm{ZrO}_{2}$ ) were performed on the $\mathrm{ZnO}$ electrodes to increase $V_{\mathrm{OC}}$ of the DSSCs. Metal alkoxide solutions of low concentrations were employed to form nanocoating layers through the dip-coating method, followed by the solgel transformation. The $\mathrm{SiO}_{2}$, the $\mathrm{Nb}_{2} \mathrm{O}_{5}$, and the $\mathrm{ZrO}_{2}$ nanocoating layers could reduce the recombination rate by constructing the energy barrier at the $\mathrm{ZnO} /$ electrolyte interface, leading to the higher $V_{\mathrm{OC}}$ values. On the other hand, the $\mathrm{TiO}_{2}$-nanocoating layers were effective to increase $V_{\mathrm{OC}}$ due to the reduction of the surface recombination sites by the grain growth of $\mathrm{ZnO}$ as well as the surface passivation. The additional effect of the coating layers was found to be the hindrance of the $\mathrm{ZnO}$ grain growth. Consequently the coated $\mathrm{ZnO}$ films maintained the high surface area to adsorb a large amount of dyes. For the $\mathrm{SiO}_{2}$ and the $\mathrm{Nb}_{2} \mathrm{O}_{5}$ coating, the energy conversion efficiency of the DSSCs increased up to $4.80 \%$ and $5.19 \%$, respectively. On the other hand, for the $\mathrm{TiO}_{2}$ and the $\mathrm{ZrO}_{2}$ coating, the slight decrease in $J_{\mathrm{SC}}$ due to the grain growth led to the lower conversion efficiency. The highest $V_{\mathrm{OC}}$ of $0.765 \mathrm{~V}$ was recorded for the $\mathrm{ZrO}_{2}$ coated $\mathrm{ZnO}$ electrode due to in the present study. Further work is ongoing to enhance the overall cell performance by optimizing the coating conditions.

\section{Acknowledgment}

S. Ueno is grateful for a JSPS Research Fellowship for Young Scientists. 


\section{References}

[1] M. Grätzel, "Solar energy conversion by dye-sensitized photovoltaic cells," Inorganic Chemistry, vol. 44, no. 20, pp. 68416851, 2005.

[2] S. Ueno, N. Hitachi, and S. Fujihara, "Nanostructural control of $\mathrm{ZnO}$ photoelectrodes for enhancing solar energy conversion efficiency in dye-sensitised solar cells," International Journal of Nanoparticles, vol. 4, no. 2-3, pp. 231-247, 2011.

[3] S. Ueno and S. Fujihara, "Effect of an $\mathrm{Nb}_{2} \mathrm{O}_{5}$ nanolayer coating on $\mathrm{ZnO}$ electrodes in dye-sensitized solar cells," Electrochimica Acta, vol. 56, no. 7, pp. 2906-2913, 2011.

[4] S. Ueno and S. Fujihara, "Formation of silica nanolayers on $\mathrm{ZnO}$ electrodes in dye-sensitized solar cells," European Journal of Inorganic Chemistry, no. 14, pp. 2165-2171, 2010.

[5] K. Sayama, H. Sugihara, and H. Arakawa, "Photoelectrochemical properties of a porous $\mathrm{Nb}_{2} \mathrm{O}_{5}$ electrode sensitized by a ruthenium dye," Chemistry of Materials, vol. 10, no. 12, pp. 3825-3832, 1998.

[6] M. Law, L. E. Greene, J. C. Johnson, R. Saykally, and P. Yang, "Nanowire dye-sensitized solar cells," Nature Materials, vol. 4, no. 6, pp. 455-459, 2005.

[7] K. Keis, C. Bauer, G. Boschloo et al., "Nanostructured ZnO electrodes for dye-sensitized solar cell applications," Journal of Photochemistry and Photobiology A, vol. 148, no. 1-3, pp. 5764, 2002.

[8] Q. Zhang, T. P. Chou, B. Russo, S. A. Jenekhe, and G. Cao, "Aggregation of $\mathrm{ZnO}$ nanocrystallites for high conversion efficiency in dye-sensitized solar cells," Angewandte ChemieInternational Edition, vol. 47, no. 13, pp. 2402-2406, 2008.

[9] Y. H. Lai, C. Y. Lin, H. W. Chen et al., "Fabrication of a ZnO film with a mosaic structure for a high efficient dye-sensitized solar cell," Journal of Materials Chemistry, vol. 20, no. 42, pp. 9379-9385, 2010.

[10] S. Yodyingyong, Q. Zhang, K. Park et al., "ZnO nanoparticles and nanowire array hybrid photoanodes for dye-sensitized solar cells," Applied Physics Letters, vol. 96, no. 7, Article ID 073115, 3 pages, 2010.

[11] S. H. Ko, D. Lee, H. W. Kang et al., "Nanoforest of hydrothermally grown hierarchical $\mathrm{ZnO}$ nanowires for a high efficiency dye-sensitized solar cell," Nano Letters, vol. 11, no. 2, pp. 666671,2011

[12] E. Hosono, S. Fujihara, and T. Kimura, "Synthesis, structure and photoelectrochemical performance of micro/nanotextured $\mathrm{ZnO}$ /eosin Y electrodes," Electrochimica Acta, vol. 49, no. 14, pp. 2287-2293, 2004.

[13] E. Hosono, S. Fujihara, I. Honma, and H. Zhou, "The fabrication of an upright-standing zinc oxide nanosheet for use in dye-sensitized solar cells," Advanced Materials, vol. 17, no. 17, pp. 2091-2094, 2005.

[14] K. Kakiuchi, E. Hosono, and S. Fujihara, "Enhanced photoelectrochemical performance of $\mathrm{ZnO}$ electrodes sensitized with N-719," Journal of Photochemistry and Photobiology A, vol. 179, no. 1-2, pp. 81-86, 2006.

[15] K. Kakiuchi, M. Saito, and S. Fujihara, "Fabrication of $\mathrm{ZnO}$ films consisting of densely accumulated mesoporous nanosheets and their dye-sensitized solar cell performance," Thin Solid Films, vol. 516, no. 8, pp. 2026-2030, 2008.

[16] M. Saito and S. Fujihara, "Large photocurrent generation in dye-sensitized $\mathrm{ZnO}$ solar cells," Energy and Environmental Science, vol. 1, no. 2, pp. 280-283, 2008.

[17] M. Saito and S. Fujihara, "Fabrication and photovoltaic properties of dye-sensitized $\mathrm{ZnO}$ thick films by a facile doctor-blade printing method using nanocrystalline pastes,"
Nippon Seramikkusu Kyokai Gakujutsu Ronbunshi/Journal of the Ceramic Society of Japan, vol. 117, no. 1367, pp. 823-827, 2009.

[18] S. Ueno and S. Fujihara, "Controlled synthesis of nanostructured $\mathrm{ZnO}$ films for use in dye-sensitized solar cells," Journal of the Electrochemical Society, vol. 158, no. 1, pp. K1-K5, 2011.

[19] S. Singh, P. Thiyagarajan, K. Mohan Kant et al., "Structure, microstructure and physical properties of $\mathrm{ZnO}$ based materials in various forms: bulk, thin film and nano," Journal of Physics D, vol. 40, no. 20, pp. 6312-6327, 2007.

[20] M. Grätzel, "Photoelectrochemical cells," Nature, vol. 414, no. 6861, pp. 338-344, 2001.

[21] M. A. Butler and D. S. Ginley, "Prediction of flatband potentials at semiconductor-electrolyte interfaces from atomic electronegativities," Journal of the Electrochemical Society, vol. 125, no. 2, pp. 228-232, 1978.

[22] H. P. Maruska and A. K. Ghosh, "A study of oxide-based heterostructure photoelectrodes," Solar Energy Materials, vol. 1, no. 5-6, pp. 411-429, 1979.

[23] G. Redmond, A. O'Keeffe, C. Burgess, C. MacHale, and D. Fitzmaurice, "Spectroscopic determination of the flatband potential of transparent nanocrystalline $\mathrm{ZnO}$ films," Journal of Physical Chemistry, vol. 97, no. 42, pp. 11081-11086, 1993.

[24] T. P. Chou, Q. Zhang, and G. Cao, "Effects of dye loading conditions on the energy conversion efficiency of $\mathrm{ZnO}$ and $\mathrm{TiO}_{2}$ dye-sensitized solar cells," Journal of Physical Chemistry C, vol. 111, no. 50, pp. 18804-18811, 2007.

[25] M. K. Nazeeruddin, A. Kay, I. Rodicio et al., "Conversion of light to electricity by cis-X2bis (2,2'-bipyridyl-4,4' dicarboxylate)ruthenium(II) charge-transfer sensitizers ( $\mathrm{X}=$ $\mathrm{Cl}^{-}, \mathrm{Br}^{-}, \mathrm{I}^{-}, \mathrm{CN}^{-}$, and $\mathrm{SCN}^{-}$) on nanocrystalline $\mathrm{TiO}_{2}$ electrodes," Journal of the American Chemical Society, vol. 115, no. 14, pp. 6382-6390, 1993.

[26] C. H. Ku and J. J. Wu, "Chemical bath deposition of $\mathrm{ZnO}$ nanowire-nanoparticle composite electrodes for use in dyesensitized solar cells," Nanotechnology, vol. 18, no. 50, Article ID 505706, 9 pages, 2007.

[27] S. G. Chen, S. Chappel, Y. Diamant, and A. Zaban, "Preparation of $\mathrm{Nb}_{2} \mathrm{O}_{5}$ coated $\mathrm{TiO}_{2}$ nanoporous electrodes and their application in dye-sensitized solar cells," Chemistry of Materials, vol. 13, no. 12, pp. 4629-4634, 2001.

[28] K. Tennakone, J. Bandara, P. K. M. Bandaranayake, G. R. A. Kumara, and A. Konno, "Enhanced efficiency of a dyesensitized solar cell made from $\mathrm{MgO}$-coated nanocrystalline $\mathrm{SnO}_{2}$," Japanese Journal of Applied Physics, Part 2, vol. 40, no. 7, pp. L732-L734, 2001.

[29] A. Kay and M. Grätzel, "Dye-sensitized core-shell nanocrystals: improved efficiency of mesoporous tin oxide electrodes coated with a thin layer of an insulating oxide," Chemistry of Materials, vol. 14, no. 7, pp. 2930-2935, 2002.

[30] P. K. M. Bandaranayake, P. V. V. Jayaweera, and K. Tennakone, "Dye-sensitization of magnesium-oxide-coated cadmium sulfide," Solar Energy Materials and Solar Cells, vol. 76, no. 1, pp. 57-64, 2003.

[31] K. Tennakone, G. R. R. A. Kumara, I. R. M. Kottegoda, and V. P. S. Perera, "An efficient dye-sensitized photoelectrochemical solar cell made from oxides of tin and zinc," Chemical Communications, no. 1, pp. 15-16, 1999.

[32] B. L. Cushing, V. L. Kolesnichenko, and C. J. O'Connor, "Recent advances in the liquid-phase syntheses of inorganic nanoparticles," Chemical Reviews, vol. 104, no. 9, pp. 3893 3946, 2004. 
[33] P. Yang, M. Ando, and N. Murase, "Encapsulation of emitting CdTe QDs within silica beads to retain initial photoluminescence efficiency," Journal of Colloid and Interface Science, vol. 316, no. 2, pp. 420-427, 2007.

[34] M. A. Aegerter, "Sol-gel niobium pentoxide: a promising material for electrochromic coatings, batteries, nanocrystalline solar cells and catalysis," Solar Energy Materials and Solar Cells, vol. 68, no. 3-4, pp. 401-422, 2001.

[35] S. D. Meetei, S. D. Singh, and V. Sudarsan, "Polyol synthesis and characterizations of cubic $\mathrm{ZrO}_{2}: \mathrm{Eu}^{3+}$ nanocrystals," Journal of Alloys and Compounds, vol. 514, pp. 174-178, 2012.

[36] Y. Du, M. S. Zhang, J. Hong, Y. Shen, Q. Chen, and Z. Yin, "Structural and optical properties of nanophase zinc oxide," Applied Physics A, vol. 76, no. 2, pp. 171-176, 2003.

[37] S. Ueno and S. Fujihara, "Influence of sintering behavior of $\mathrm{ZnO}$ nanoparticles on J-V characteristics of $\mathrm{ZnO}$-based dyesensitized solar cells," Key Engineering Materials, vol. 445, pp. 117-120, 2010.

[38] E. Palomares, J. N. Clifford, S. A. Haque, T. Lutz, and J. R. Durrant, "Control of charge recombination dynamics in dye sensitized solar cells by the use of conformally deposited metal oxide blocking layers," Journal of the American Chemical Society, vol. 125, no. 2, pp. 475-482, 2003.

[39] F. Lenzmann, J. Krueger, S. Burnside et al., "Surface photovoltage spectroscopy of dye-sensitized solar cells with $\mathrm{TiO}_{2}$, $\mathrm{Nb}_{2} \mathrm{O}_{5}$, and $\mathrm{SrTiO}_{3}$ nanocrystalline photoanodes: indication for electron injection from higher excited dye states," Journal of Physical Chemistry B, vol. 105, no. 27, pp. 6347-6352, 2001.

[40] K. Tennakone and J. Bandara, "Multiphoton semiconductor photocatalysis," Solar Energy Materials and Solar Cells, vol. 60, no. 4, pp. 361-365, 2000.

[41] R. Katoh, A. Furube, T. Yoshihara et al., "Efficiencies of Electron Injection from Excited $\mathrm{N} 3$ Dye into Nanocrystalline Semiconductor $\left(\mathrm{ZrO}_{2}, \mathrm{TiO}_{2}, \mathrm{ZnO}, \mathrm{Nb}_{2} \mathrm{O}_{5}, \mathrm{SnO}_{2}, \mathrm{In}_{2} \mathrm{O}_{3}\right)$ Films," Journal of Physical Chemistry B, vol. 108, no. 15, pp. 4818-4822, 2004.

[42] M. Law, L. E. Greene, A. Radenovic, T. Kuykendall, J. Liphardt, and P. Yang, " $\mathrm{ZnO}-\mathrm{Al}_{2} \mathrm{O}_{3}$ and $\mathrm{ZnO}-\mathrm{TiO}_{2}$ core-shell nanowire dye-sensitized solar cells," Journal of Physical Chemistry B, vol. 110, no. 45, pp. 22652-22663, 2006.

[43] Y. Y. Xi, Y. F. Hsu, A. B. Djurišić, and W. K. Chan, "Electrochemical synthesis of $\mathrm{ZnO}$ nanoporous films at low temperature and their application in dye-sensitized solar cells," Journal of the Electrochemical Society, vol. 155, no. 9, pp. D595-D598, 2008.

[44] F. Fabregat-Santiago, J. García-Cañadas, E. Palomares et al., "The origin of slow electron recombination processes in dyesensitized solar cells with alumina barrier coatings," Journal of Applied Physics, vol. 96, no. 11, pp. 6903-6907, 2004.

[45] H. Chen, A. Du Pasquier, G. Saraf, J. Zhong, and Y. Lu, "Dyesensitized solar cells using $\mathrm{ZnO}$ nanotips and Ga-doped $\mathrm{ZnO}$ films," Semiconductor Science and Technology, vol. 23, no. 4, Article ID 045004, 6 pages, 2008. 


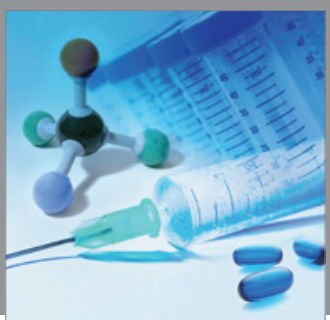

International Journal of

Medicinal Chemistry

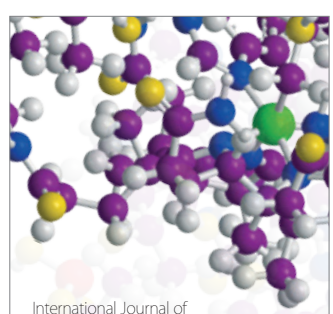

Carbohydrate Chemistry

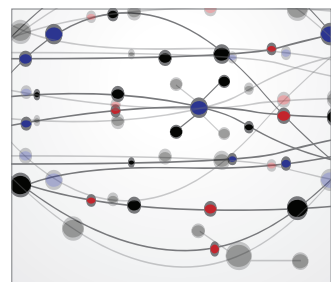

The Scientific World Journal
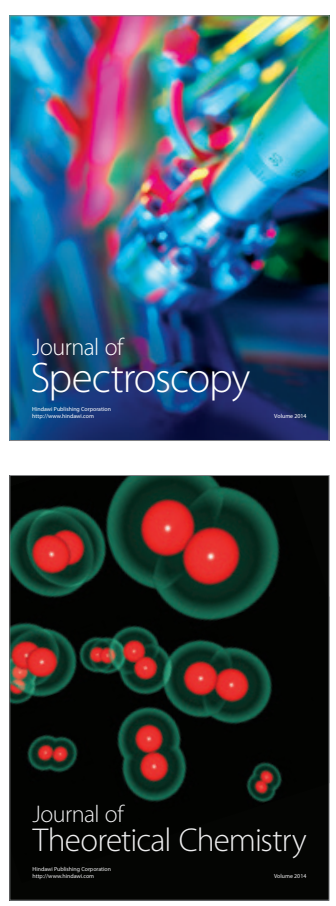
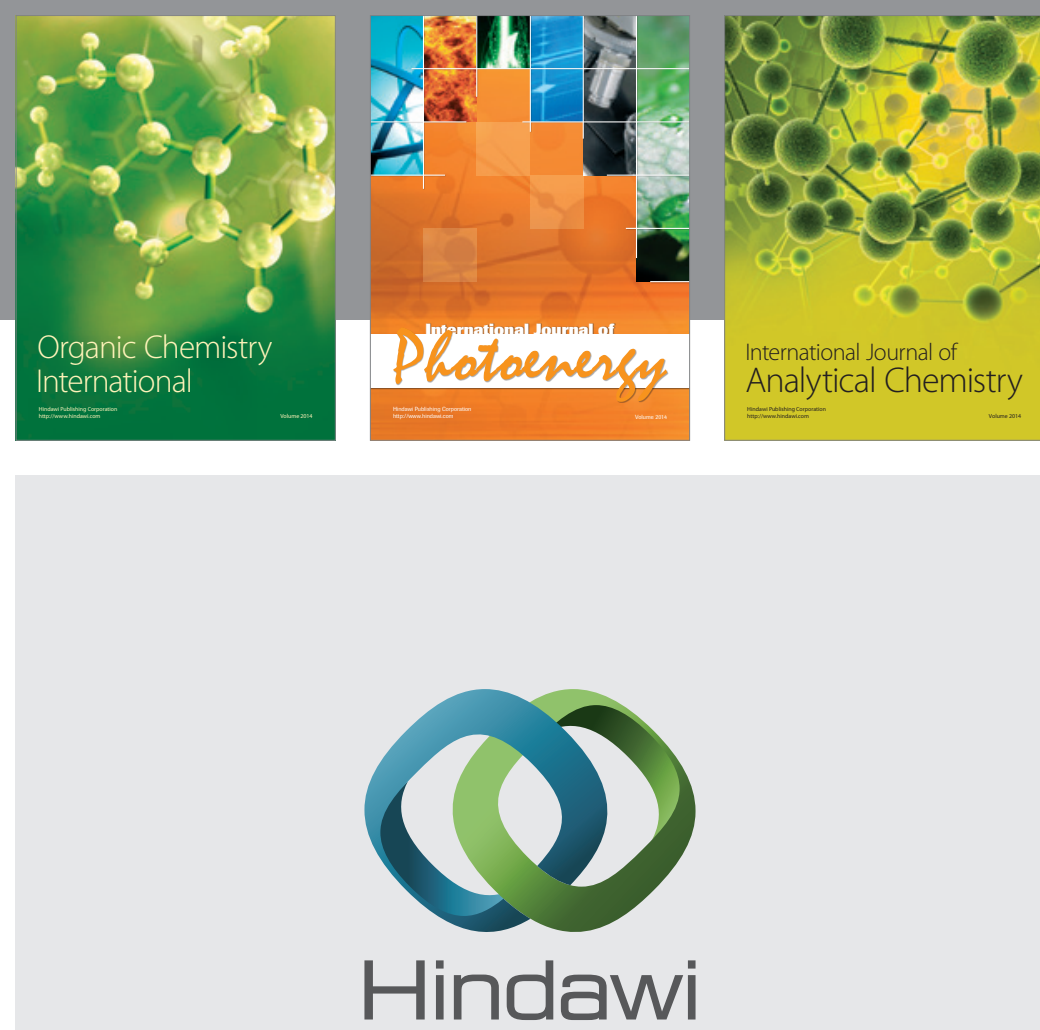

Submit your manuscripts at

http://www.hindawi.com
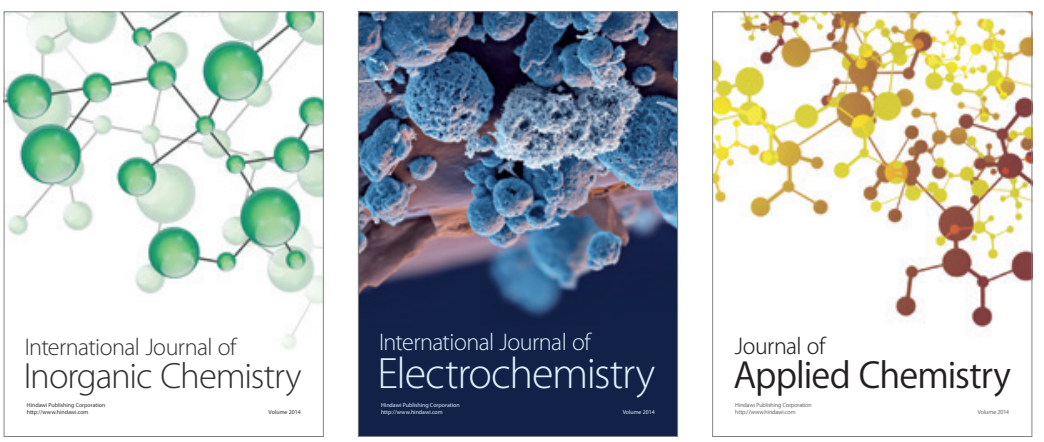

Journal of

Applied Chemistry
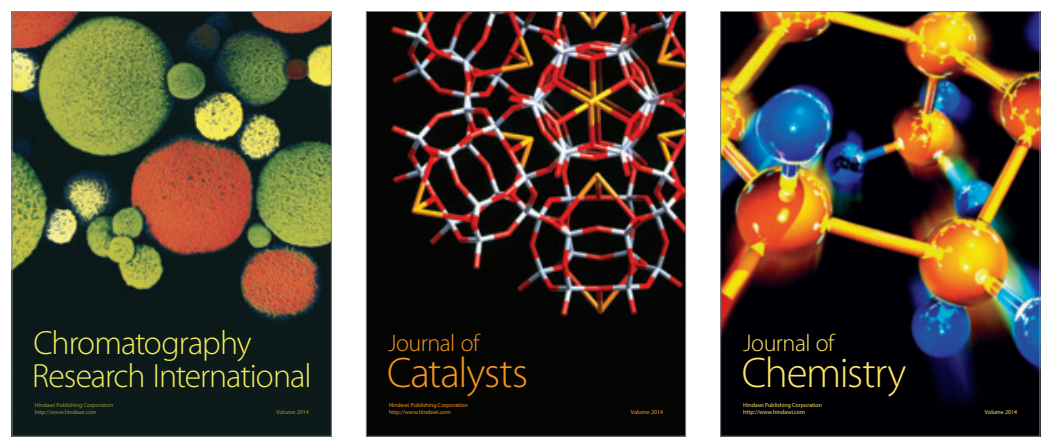
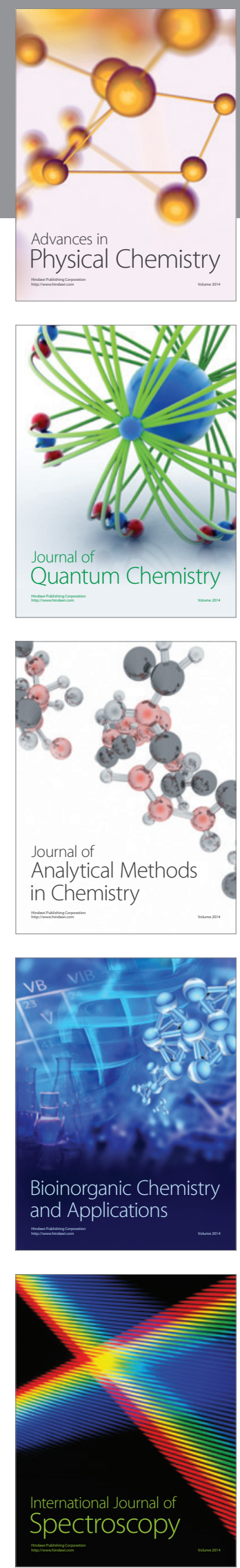